\title{
Mortality among chemical workers in a factory where formaldehyde was used
}

\author{
Gary M Marsh, Roslyn A Stone, Nurtan A Esmen, Vivian L Henderson, Kyung Y Lee
}

\begin{abstract}
Objectives-An independent and updated historical cohort mortality study was conducted among chemical plant workers to investigate further an association between exposures to formaldehyde and particulates and cancers of the nasopharynx and lung reported in an earlier National Cancer Institute study of the same plant. Methods-Subjects were 7359 workers who were first employed between 1941 and 1984 in a factory in Wallingford, Connecticut where formaldehyde was used. Vital status was determined on 31 December 1984 for $96 \%$ of the cohort and death certificates were obtained for $93 \%$ of 1531 known deaths. Exposures of individual workers were estimated quantitatively for formaldehyde, product particulates, and non-product particulates, and qualitatively for pigment. Statistical analyses focused on 6039 white men in 1945-84. Cohort data that could not have been included in the National Cancer Institute study were also analysed separately.
\end{abstract}

Results-Mortality among long term workers (employed $\geqslant 1$ y) was generally similar to or more favourable than that of the general population, and there was little evidence of a relation between either rates of lung cancer or standardised mortality ratios (SMRs) and several measures of exposure to formaldehyde, particulates, and pigment. For several causes including lung cancer, death rates among short term workers (employed < 1 y) were significantly increased. Short term workers did not seem to differ from long term workers for the exposures considered. Among all white men, a significant SMR of 550 (local comparison) for nasopharyngeal cancer (NPC) was based on the same four index cases identified in the earlier study of this plant. Only one case of nasopharyngeal cancer had any appreciable exposure to formaldehyde. No new cases of nasopharyngeal cancers were found among the cohort data that could not have been included in the National Cancer Institute study-that is, extended observation time and additional study members.

Conclusions-Among workers employed for at least one year, this study provides little evidence that the risk of lung cancer is associated with exposure to formaldehyde alone or in combination with particulates or pigment. The significant increases in both the rates and SMRs for lung cancer seem to be primarily a phenomenon of short term workers, but the possibility remains that unmeasured occupational or non-occupational factors may have played a part.

(Occup Environ Med 1996;53:613-627)

Keywords: nasopharyngeal cancer; lung cancer; formaldehyde; particulates; historical cohort study

In 1986, Blair et al reported a National Cancer Institute cohort mortality study of 26561 workers employed at some time before 1966 in one or more of 10 factories that produced or used formaldehyde in the United States. Their study was prompted by earlier inhalation studies in laboratory animals that linked exposure to formaldehydes with nasal cancer in rats, ${ }^{23}$ and by previous epidemiological studies that reported some associations between exposure to formaldehyde and leukaemia and cancers of the brain, lung, buccal cavity, and pharynx. ${ }^{4}$ The National Cancer Institute study did not show any excess nasal tumours among workers exposed to formaldehyde and provided little evidence that mortality from cancer is associated with exposure to formaldehyde at the levels experienced. Additional review of the National Cancer Institute cohort data did show a significant excess of nasopharyngeal cancer (four observed, less than one expected) among a subcohort of 4389 workers and were employed during the 1950s in an American Cyanamid Company plant in Wallingford, Connecticut where formaldehyde was used.

Because of the small numbers of deaths and the inability to control for potentially confounding factors in the National Cancer Institute study, definitive conclusions could not be drawn from the findings for nasopharyngeal cancer. For example, two of the four cases occurred among short term employees with work histories of only three and seven months, and, before their work at Wallingford, three of the four cases were employed in jobs involving exposure to metal fumes or dust, two substances that have been associated with excess cancers of the nasopharynx. ${ }^{5}$ Despite these limitations, certain occupational exposure factors at the Wallingford plant prompted further examination of the excess of nasopharyngeal cancers. Specifically, certain work areas in the plant were associated with exposures to formaldehyde in conjunction with particulate matter derived from the paper pulp 
products that have been routinely mixed with urea, melamine, and other substances to produce a variety of plastic products. As well as paper pulp, other materials containing cellulose such as walnut and pecan shells were used throughout the plant's history to impart desirable physical characteristics to the plastic and resin products.

In the National Cancer Institute study, standardised mortality ratios (SMRs) for cancer of the buccal cavity and pharynx, cancer of the brain, and Hodgkin's disease were higher among those with exposure to particulates containing formaldehyde than among those never exposed to such dusts. An analysis of the excess of cancer of the buccal cavity or pharynx by subsite indicated that the risk for the nasopharynx was significantly increased among people exposed to particulates. However, the overall risk did not rise consistently with increasing exposure for this or any other subsite. ${ }^{1}$

In 1987, Blair et al reported an additional analysis of the excess of nasopharyngeal cancer and concluded that "the pattern for nasopharyngeal cancer suggests that simultaneous exposure to formaldehyde and particulates may be a risk factor for this tumor". ${ }^{6}$ This conclusion was subsequently challenged on methodological and other grounds by Collins et $a l^{7}$ who later performed a reanalysis of the total National Cancer Institute cohort and an updated analysis of the Wallingford plant cohort. $^{8}$ Neither of these analyses supported an association between nasopharyngeal cancer and joint exposure to formaldehyde and particulates. Although the update added five years of follow up to the Wallingford cohort, no additional cases of nasopharyngeal cancer were found.

Several extensive reanalyses of the National Cancer Institute total cohort data were subsequently performed.9-15 These analyses have shown differential mortality patterns for short term (employed < 1y) versus long term (employed $\geqslant 1 y$ ) workers and have provided evidence that certain coexposures associated with the production of resins and moulding compounds-for example, phenol, melamine, urea, and wood dust-may play a part in the risk of lung cancer. Data limitations preclude a reliable examination of the part of coexposures in the individual plants.

In 1987, the American Cyanamid Company commissioned the University of Pittsburgh, Department of Biostatistics, to perform an updated and extended investigation of total and cause specific mortality among the workforce of the Wallingford plant with special emphasis on the association between exposures to formaldehyde and particulates and cancers of the nasopharynx and lung. Although certain epidemiological findings of this research are summarised in a brief report, ${ }^{16}$ other important findings and much of the analytical and methodological details were omitted. We report here a more comprehensive account of our findings, including a more detailed exposition of the historical exposure assessment that was performed to estimate exposures of individual workers to formalde- hyde, particulates, and pigment. We also report new results of an analysis of the cohort data not included in the earlier National Cancer Institute study, and a comparative descriptive analysis of exposure data developed independently for the National Cancer Institute and University of Pittsburgh studies.

\section{Methods}

Operationally, the Wallingford cohort study was a collaborative effort between the University of Pittsburgh and the American Cyanamid Company. The American Cyanamid Company was responsible for the collection, coding, and computer processing of all primary study data, and the University of Pittsburgh was responsible for verifying the accuracy and completeness of the cohort data and for performing the statistical analysis and interpretation of the mortality data. Cohort tracing activities and the exposure assessment of the Wallingford plant environment were shared by the two organisations.

\section{STUDY POPULATION}

The National Cancer Institute study of the Wallingford plant included all workers $(n=$ 4389) first employed from the plant's start up date in 1941 to the end of 1965 , with vital status determined up to 1 December 1979. In the present study, the Wallingford cohort was independently enumerated from plant and corporate records, and the study population enlarged to include all workers who began employment between 1941 and 1984. The follow up period was also extended by five years up to 31 December 1984.

The required demographic and work history data were available for virtually all eligible study members. The completeness and accuracy of our cohort enumeration were verified with methods previously developed. ${ }^{17}{ }^{18} \mathrm{~A}$ total of 7359 workers were found to be eligible for our Wallingford cohort, an increase of 2970 over the National Cancer Institute cohort. Work history data included 32522 jobs representing 4322 unique department and job title combinations. Because smoking history data were available for only $30 \%$ of the cohort, they were not used in the analysis. Appendix A shows a comparison of selected Wallingford cohort data from the current study and from the National Cancer Institute study (plant 1) as developed for the reanalyses performed by Marsh et al. ${ }^{1011}$

\section{COHORT TRACING}

Vital status of the cohort was determined on 31 December 1984 from available plant record information as well as a variety of routine federal, state, and local sources (Social Security Administration, National Death Index, US Postal Service, Pension Benefits Company, state motor vehicle bureaux, personal contacts, and other sources). A $10 \%$ random sample of people identified as alive by the American Cyanamid Company was submitted for death clearance through other sources to verify the plant based data.

For each worker identified as dead, a death 
Table 1 Distribution of total Wallingford cohort by vital status on 31 December 1984 race, and sex

\begin{tabular}{lccccc}
\hline & $\begin{array}{l}\text { White men } \\
n(\%)\end{array}$ & $\begin{array}{l}\text { Non-white } \\
\text { men } \\
n(\%)\end{array}$ & $\begin{array}{l}\text { White women } \\
n(\%)\end{array}$ & $\begin{array}{l}\text { Non-white } \\
\text { women } \\
n(\%)\end{array}$ & $\begin{array}{l}\text { Total } \\
n(\%)\end{array}$ \\
Vital status & $4461(73 \cdot 5)$ & $349(84 \cdot 1)$ & $652(79 \cdot 3)$ & $53(98 \cdot 1)$ & $5515(74 \cdot 9)$ \\
\hline Alive & $1402(23 \cdot 1)$ & $57(13 \cdot 7)$ & $72(8 \cdot 8)$ & $0(0 \cdot 0)$ & $1531(20 \cdot 8)$ \\
Dead: & $51(89 \cdot 5)$ & $63(87 \cdot 5)$ & - & $1424(93 \cdot 0)$ \\
Death certificate $1310(93 \cdot 4)$ & $92(6 \cdot 6)$ & $6(10 \cdot 5)$ & $9(12 \cdot 5)$ & - & $107(7 \cdot 0)$ \\
Presumed dead & $925(3 \cdot 4)$ & $9(2 \cdot 2)$ & $98(11 \cdot 9)$ & $1(1.9)$ & $313(4 \cdot 3)$ \\
Unknown & $6068(100 \cdot 0)$ & $415(100 \cdot 0)$ & $822(100 \cdot 0)$ & $54(100 \cdot 0)$ & $7359(100 \cdot 0)$ \\
Total & & & & &
\end{tabular}

certificate was obtained from the state in which the death occurred unless one had already been obtained from the American Cyanamid Company. The underlying cause of death was coded by an independent nosologist according to the international classification of diseases (ICD) rules in effect at the time of death, to assure comparability with standard population death rates.

Table 1 shows the distribution of updated Wallingford cohort by race and sex. Overall, vital status was obtained for all but 313 people $(4.3 \%)$ and death certificates were found for $1424(93 \%)$ of the 1531 identified deaths. The mortality analysis is limited to the subcohort of 6039 white men during the follow up period 1945-84 to obviate sparse data problems in the other race and sex categories and possible selection biases in studying civilian men employed during the years of the second world war.

\section{EXPOSURE ASSESSMENT}

General description of the Wallingford plant

The American Cyanamid Company Wallingford plant was built in 1941 for the production of thermosetting resins and industrial moulding compounds and has been in continuous operation since 1943. It consists of 35 buildings located on 250 acres. When the plant opened in 1941 there were 300 employees. The maximum number of employees was around 1200 in the early 1970s and in recent years the average work force has been around 700 employees. In 1943, the resins department began producing several product lines including paper product resins made from acrylamide, laminating resins made from urea, melamine, and formaldehyde and methylated resins made from melamine, formaldehyde, and various alcohols. The production of thermoplastic moulding compounds began in 1965. The thermoset moulding compounds product line consists of BEETLE, which is formulated from urea and formaldehyde and CYMEL, which is formulated from melamine and formaldehyde. These compounds are manufactured from methyl methacrylate, acrylonitrile, styrene, polybutadiene, and other acrylate monomers. The newest production facility for metal coated fibres was commissioned by the American Cyanamid Company in 1983. These materials are made by plating metals on carbon fibres and are used for lightning protection and for electromagnetic and radio frequency shielding applications.

\section{Basic exposure estimation procedure}

The exposure estimation portion of the Wallingford cohort study was based on an examination of the available sampling data and job descriptions as well as on verbal descriptions of jobs and tasks by plant personnel, including the plant industrial hygienist. The data received by the University of Pittsburgh from the American Cyanamid Company included 156 detailed job and task descriptions, a description of past and present operations in various buildings and departments, a summary of major changes, several lists of chemicals used, and the available sampling data. Especially important in the job and task descriptions were the notations for the fraction of time a worker was expected to be performing certain tasks and the comfort level of the job as measured by dustiness and odours. These notations were an important surrogate for actual measurements.

Although several pigments used in 1955-65 were of special interest for their potential toxicity, it was not possible to specify exposure to the components of pigment from the available list of pigments used, or to estimate that exposure quantitatively; adequate measurements of airborne pigment levels were not available. Pigment exposure was assessed in terms of the presence or absence of any pigment. Because the focus of this study was on exposure to formaldehyde alone and in combination with particulates, or pigment, or both, no attempt was made to characterise other chemical exposures.

The available sampling data were sporadic measurements between 1965 and 1987 for 42 job titles (about $17 \%$ of the final 235 job classifications). The highest reported eight hour time weighted average (TWA) exposure to formaldehyde was $2.8 \mathrm{ppm}$ in 1972 . There were only 12 measurements in excess of $1.0 \mathrm{ppm}$ TWA. The few jobs that were sampled repeatedly over the years did not show a consistent decline or increase in the measured exposure to formaldehyde. This is consistent with the American Cyanamid Company reports of few operational changes over the years, none of which influenced the measured exposures dramatically. Albeit limited, the available sampling data are consistent with a constant level of exposure over time.

The general approach used in assigning exposure was the classification of job titles by the similarity of tasks performed and the likelihood for potential exposures, as previously described. ${ }^{19} 20$ Exposures were initially assigned to each job and task combination by the consultant industrial hygienist on a ranked scale between background (or zero) exposure and high exposure to formaldehyde and particulate matter. These rankings provided seven classes $(0-6)$ for formaldehyde and nine classes $(0-8)$ for product based particulate and non-product particulate matter.

Subjective ranking of each of 156 unique job descriptions was based on potential for exposure to each agent in relation to physical proximity of jobs and duties relative to operation processes, accounting for duration, intensity, and frequency of exposure. Supporting documentation of use of personal protection equipment in response to concerns about noise and dust were also used in developing the rankings. The remaining job titles were classified accord- 
ing to their similarity to the 156 job and task descriptions. An additional 79 job numbers were created to classify titles that were not comparable with any of the previously identified jobs. The resultant job classifications and exposure rankings were then sent to American Cyanamid Company to be reviewed by corporate and industrial hygienists to assess accuracy and relative potential exposure.

A range of exposures for each ranking were then assigned to the job categories. Although the assigned exposures suggest physical measurements, the exposure estimates should be considered to be relative within the study. It has been shown that on such a relative scale, the exposure estimates are satisfactory, ${ }^{21}$ and after calibrating the "experts", the accuracy of estimates improve substantially. ${ }^{22}$ Appendix B provides a more detailed account of the methods used to assign exposures.

The present study was designed to expand the Wallingford plant component of the National Cancer Institute study. ${ }^{1}$ To compare the results of the present study with the National Cancer Institute study, similar exposure to formaldehyde categories were adopted, based on a modified National Cancer Institute schema. In the National Cancer Institute study, exposure to formaldehyde was classified into five categories defined as: trace (having worked at a plant that used or produced formaldehyde but with no known exposure), $<0.1 \mathrm{ppm}$, $0.1-0.5 \mathrm{ppm}, 0.5-2 \mathrm{ppm}$, and $>2 \mathrm{ppm}$. Three minor modifications were made in the treatment of jobs with very low exposure: (a) the worker classifications such as "office help" were presumed to be exposed only to background levels of formaldehyde and such workers were assigned a zero exposure, $(b)$ the workers who were estimated to be very indirectly exposed to formaldehyde were assigned background exposure, and $(c)$ the estimated relative exposures were assumed to hold over time.

To summarise the exposure estimation process, $\mathbf{4 3 2 2}$ job titles examined for the white male cohort were classified into 235 job numbers and assigned exposure to formaldehyde values similar, with modifications, to the scheme used in the National Cancer Institute study. Additionally, each job number specifies a set of exposure concentrations for product particulate and non-product particulate, and a unit step function for exposure to pigment.

\section{Development of exposure indices for individual workers}

The occupational history of each study member was linked to the estimated airborne exposure concentrations to estimate cumulative exposure, average intensity and duration of exposure to formaldehyde, and to the two coexposures, (product particulates and non-product particulates). Pigment exposure was assessed as duration of exposure to pigment. Exposure to formaldehyde occurring in the same job, but not necessarily simultaneously, with each of the three coexposures (formaldehyde/product particulates, formaldehyde/non-product particulates, formaldehyde/pigment) was also assessed.

For the calculation of cumulative and mean exposures, the numerical value given to each exposure interval is the geometric midpoint of each interval. Duration of exposure to each agent was calculated by summing the years at each job in a worker's history in which a nonzero exposure to a given agent occurred. The time weighted cumulative exposure was found for each agent by multiplying the job class specific estimated mean exposure by years at that job, and summing this product across all jobs. The average intensity of exposure for each agent was found by dividing time weighted exposure by duration of exposure, where $0 / 0$ was defined to be 0 . By this definition intensity of exposure is the average intensity during periods when each worker was exposed. The class intervals for the time weighted exposure, duration of exposure, and average intensity of exposure measures were constructed a priori when possible to resemble those used for the same measures in the National Cancer Institute study. ${ }^{1}$ Otherwise, intervals were defined to evenly distribute the observed number of deaths from lung cancer. Short and long term workers $(<1, \geqslant 1 \mathrm{y})$ were defined as in the reanalysis of the National Cancer Institute cohort by Stewart et al. ${ }^{15}$

An alternative characterisation of exposure focused on jobs with high mean formaldehyde exposures. Duration of exposure in jobs with mean formaldehyde exposures that were $\geqslant 0.2$ ppm and duration of exposure in jobs with mean formaldehyde exposures that were $\geqslant 0.7 \mathrm{ppm}$ were computed. Appendix $\mathrm{C}$ shows the definitions of the study variables.

To assess the comparability of historical exposure data from the Wallingford plant developed independently for the National Cancer Institute and University of Pittsburgh studies, we performed both matched and unmatched descriptive analyses of selected exposure factors for white male members of both cohorts. Appendix D shows methodological details and results of the comparative analysis.

\section{STATISTICAL ANALYSIS}

Analyses of general patterns of mortality in the cohorts were performed with the occupational cohort mortality analysis program (OCMAP) developed at the University of Pittsburgh. ${ }^{23-25}$ Person-years at risk contributed by each study member were jointly classified by calendar period, age group, duration of employment, and the corresponding time since first employment. Person-year counts relative to non-zero time weighted exposure and duration of exposure began on the starting date of the first job in the work history that was associated with a nonzero exposure to each agent. In analyses by term of employment (short term $v$ long term workers), person-years for long term workers began on the date that the first cumulative year of employment was reached. For the 313 workers lost to follow up, person-years were accumulated until the last point of verifiable vital status, which in every case was the date of the end of employment.

Expected numbers of deaths for selected causes were computed by multiplying United States mean annual age and time specific white male death rates by the person-years at risk in 
the corresponding age-time intervals. To help adjust for geographic variations in mortality, expected numbers of deaths were also computed with rates for the state of Connecticut and for the combined New Haven and Middlesex counties, the local area from which the cohort was largely drawn. State and county rates were obtained from the mortality and population data system (MPDS) maintained at the University of Pittsburgh, Department of Biostatistics. ${ }^{26}$ Because MPDS death rates are not available before 1950 for malignant neoplasms or before 1962 for non-cancer causes, in this study the expected cancer deaths for the period 1945-9 were estimated with MPDS data for the years 1950-4, and the expected noncancer deaths for the period 1960-1 were estimated with MPDS data for the years 1962-4. The expected numbers of non-cancer deaths during 1948-59 were not computed with state or county rates.

Mortality excesses and deficits are expressed as standardised mortality ratios (SMRs), the ratio of observed deaths to expected deaths ( $\times 100)$. The SMRs were computed for subgroups of the cohort defined by age group, period, year of hire, duration of employment, time since first employment, and term of employment. Significant deviations of the SMR from 100, indicating deficit or excess risks of mortality, were identified with the Poisson probability distribution. ${ }^{27}$ No formal adjustments were made for the many statistical comparisons that were made in the analysis. To facilitate the presentation of results, observed deaths and SMRs are shown with the codes (not the rules) of the ICD 8th revision (ICD-8) only.

\section{Analysis of cohort data unique to present study}

A separate analysis was performed to examine the Wallingford cohort data that by definition could not have been included in the previous National Cancer Institute study. Because individual identifiers were unavailable on our version of the National Cancer Institute cohort data file, the data not from the National Cancer Institute study were identified by selecting the workers who were hired between 1 January 1966 (the latest National Cancer Institute hire date) and 31 December 1984 (stop date of our study), and workers who were hired before 1 January 1966 and were alive on 1 January 1980 (stop date of the National Cancer Institute study). The mortality experience of workers hired in 1966-84, who could not have been included in the National Cancer Institute study, was examined between 1 January 1966 and 31 December 1984; the mortality experience of the workers hired before 1966 was examined during the additional follow up between 1 January 1980 and 31 December 1984. This analysis focused on local county comparisons of malignant respiratory diseases and was based on 1290 and 3538 white males from the two groups, respectively, who together contributed 31400 person-years at risk.

Poisson regression modelling of cohort death rates and SMRs for lung cancer

Poisson regression modelling was used to inves- tigate the dependence of the internal cohort rates and the SMRs for lung cancer (including cancer of the bronchus, trachea, or lung) on combinations of the categorical exposure and potential confounding variables of interest. This approach is described elsewhere. ${ }^{28}$ Briefly, the observed number of deaths in a particular cross classification is assumed to follow a Poisson distribution with a mean that depends on the person-years at risk (for internal cohort rates) or the expected numbers of deaths (for SMRs), and the effects of the classification factors. A multiplicative form of the model was assumed, so for cohort rates:

$\log \mathrm{E}$ (observed deaths) $=\log$ (personyears) $+\mathbf{a}^{\prime} \mathbf{z}$

and for SMRs:

$\log \mathrm{E}$ (observed deaths) $=\log$ (expected deaths) $+\mathbf{b}^{\prime} \mathbf{z}$

where $\mathrm{E}$ denotes statistical expectation, $\log$ denotes natural logarithm, $a^{\prime}$ and $b^{\prime}$ are vectors of regression coefficients to be estimated, and $z$ is the corresponding vector of covariates.

Parameters that allow separate effects for each age-time combination were included in every model for the cohort rates. These agetime parameters were also added to the models for the SMRs after the exposure effects were assessed, as a check on the homogeneity assumption of the SMRs across age and time intervals. Due to existing limitations in the OCMAP no more than two time dependent measures (as well as age group and period) could be analysed simultaneously, so time dependent exposures of interest were evaluated pairwise in separate models. Poisson regression models were fitted to the cohort rates and SMRs with maximum likelihood estimation in the generalised linear interactive modelling (GLIM) program. ${ }^{29}$ All cells with no expected deaths were excluded from the analysis for numerical reasons.

Cohort rates and SMRs were modelled as a function of the categorical classification factors in a forward stepwise approach. The significance of each main effect (expressed as global $P$ value) and interaction was assessed with a likelihood ratio statistic, with a $P$ value between 0.05 and 0.10 identified as of borderline significance. Also, a test for linear trend (expressed as trend $P$ value) was conducted on each quantitative exposure variable.

The primary Poisson regression analysis focused on 113 deaths from lung cancer among the 6039 white male study members. Some analyses were repeated on two separate subgroups of the cohort, the short term and long term workers. The 50 deaths from lung cancer among the 2590 long term workers would be expected to be more informative than data on the short term workers about risk of lung cancer associated with employment at the Wallingford plant. The very small numbers of deaths precluded Poisson regression modelling of nasopharyngeal cancer.

\section{Results}

EXPOSURE ASSESSMENT

Table 2 presents selected exposure characteristics of the white male cohort by year of hire 
and term of employment. The year of hire groupings are those used by Collins et al ${ }^{8}$ to reflect periods of the Wallingford plant history that were homogeneous for processes, products, and ostensibly, worker exposure. Shown in each cell of table 2 are the number (\%) of workers exposed and the median average intensity of exposure (based on exposed jobs only) among those exposed. Median average intensity of exposures are not defined for pigment, formaldehyde $\geqslant 0.2 \mathrm{ppm}$, and formaldehyde $\geqslant 0.7 \mathrm{ppm}$.

The recommended guideline for exposure to formaldehyde in a workplace has changed from a ceiling of $2 \mathrm{ppm}$ as late as $1979^{30}$ to the currently recommended ceiling levels $0.1 \mathrm{ppm}$ by the National Institute for Occupational Safety and Health (NIOSH) ${ }^{31}$ and 0.3 ppm by the American Conference of Governmental Industrial Hygienists (ACGIH). ${ }^{32}$ During the 1945-84 study period, the measured formaldehyde concentrations in the Wallingford plant were generally low compared with the contemporaneously recommended exposure guidelines of 1-2 ppm, although the historical exposures are comparable or slightly in excess of the currently recommended levels.

Table 2 shows that, for the total cohort, slightly higher proportions of short term than long term workers were exposed to each of the agents formaldehyde, product particulates, non-product particulates, formaldehyde and product particulates, and formaldehyde and non-product particulates, but for each agent the median intensity of exposure for the long term workers was at least twice as high as the corresponding median intensity of exposure for the short term workers. These same patterns were found for formaldehyde, nonproduct particulates, formaldehyde and product particulates, and formaldehyde and non-product particulates but not for product particulates in the separate analyses of the 1941-6 and 1947-56 year of hire subgroups. Less than a twofold differential was found in the median intensity of exposure to product particulates between the short term and long term workers in both these year of hire subgroups. Among those hired after 1956, median intensity of exposure to each of formaldehyde, product particulates, formaldehyde and product particulates, and formaldehyde and nonproduct particulates was at least as high for short term as long term workers. Overall and in the separate year of hire subgroups, consistently higher percentages of long term workers than short term workers were ever exposed to pigment, formaldehyde and pigment, formaldehyde $\geqslant 0.2 \mathrm{ppm}$, and formaldehyde $\geqslant 0.7 \mathrm{ppm}$. For the composite exposure variable, formaldehyde and pigment, the median intensity of exposure was identical for short and long term workers in the early and late year of hire subgroups, but over two times higher among short term workers than long term workers for those hired between 1947 and 1956. Although not shown, the median intensity of exposures of the long term workers during their first year of employment was generally similar to the intensity of exposures computed over the entire work history.

Table 2 Selected exposure characteristics of a white male cohort by year of hire and term of employment, showing median average intensity of exposures (AIE) *

\begin{tabular}{|c|c|c|c|c|c|c|c|c|}
\hline & \multicolumn{8}{|c|}{ Year of hire } \\
\hline & \multicolumn{2}{|l|}{ Total } & \multicolumn{2}{|c|}{$1941-6$} & \multicolumn{2}{|c|}{$1947-56$} & \multicolumn{2}{|c|}{$\geqslant 1957$} \\
\hline & $S T W$ & $L T W$ & $S T W$ & $L T W$ & $S T W$ & $L T W$ & $S T W$ & $L T W$ \\
\hline $\begin{array}{l}\text { Workers (n) } \\
\text { STW/LTW (\%) }\end{array}$ & $\begin{array}{r}3449 \\
57 \cdot 1\end{array}$ & $\begin{array}{l}2590 \\
42 \cdot 9\end{array}$ & $\begin{array}{l}504 \\
57 \cdot 9\end{array}$ & $\begin{array}{l}366 \\
42 \cdot 1\end{array}$ & $\begin{array}{l}1727 \\
62 \cdot 1\end{array}$ & $\begin{array}{l}1053 \\
37 \cdot 9\end{array}$ & $\begin{array}{l}1218 \\
50 \cdot 9\end{array}$ & $\begin{array}{l}1171 \\
49 \cdot 1\end{array}$ \\
\hline \multicolumn{9}{|l|}{$\begin{array}{l}\text { Exposure variablet: } \\
\text { F: }\end{array}$} \\
\hline $\begin{array}{l}\text { Exposed (n) } \\
\text { Exposed (\%) } \\
\text { Median AIE (ppm) }\end{array}$ & $\begin{array}{r}2922 \\
84 \cdot 7 \\
0.07\end{array}$ & $\begin{array}{c}2057 \\
79 \cdot 4 \\
0 \cdot 16\end{array}$ & $\begin{array}{l}406 \\
80 \cdot 6 \\
0 \cdot 02\end{array}$ & $\begin{array}{l}268 \\
73 \cdot 2 \\
0 \cdot 11\end{array}$ & $\begin{array}{c}1570 \\
90 \cdot 9 \\
0.02\end{array}$ & $\begin{array}{l}931 \\
88 \cdot 4 \\
0 \cdot 15\end{array}$ & $\begin{array}{l}946 \\
77 \cdot 7 \\
0 \cdot 20\end{array}$ & $\begin{array}{l}858 \\
73 \cdot 3 \\
0 \cdot 18\end{array}$ \\
\hline $\begin{array}{l}\text { PP: } \\
\text { Exposed (n) } \\
\text { Exposed (\%) } \\
\left.\text { Median AIE (mg/m }{ }^{3}\right)\end{array}$ & $\begin{array}{l}2653 \\
76 \cdot 9 \\
0 \cdot 20\end{array}$ & $\begin{array}{c}1844 \\
71 \cdot 2 \\
0 \cdot 43\end{array}$ & $\begin{array}{c}379 \\
75 \cdot 2 \\
0 \cdot 20\end{array}$ & $\begin{array}{c}239 \\
65 \cdot 3 \\
0 \cdot 20\end{array}$ & $\begin{array}{c}1532 \\
88 \cdot 2 \\
0 \cdot 20\end{array}$ & $\begin{array}{l}876 \\
83 \cdot 2 \\
0 \cdot 31\end{array}$ & $\begin{array}{l}751 \\
61 \cdot 7 \\
1 \cdot 18\end{array}$ & $\begin{array}{l}729 \\
62 \cdot 3 \\
0 \cdot 89\end{array}$ \\
\hline $\begin{array}{l}\text { NPP: } \\
\text { Exposed (n) } \\
\text { Exposed (\%) } \\
\left.\text { Median AIE (mg/m } \mathrm{m}^{3}\right)\end{array}$ & $\begin{array}{c}3010 \\
87 \cdot 3 \\
0.02\end{array}$ & $\begin{array}{l}2101 \\
81 \cdot 1 \\
0.09\end{array}$ & $\begin{array}{l}399 \\
79 \cdot 2 \\
0 \cdot 04\end{array}$ & $\begin{array}{l}275 \\
75 \cdot 1 \\
0 \cdot 08\end{array}$ & $\begin{array}{l}1584 \\
91 \cdot 7 \\
0 \cdot 02\end{array}$ & $\begin{array}{l}937 \\
89.0 \\
0.07\end{array}$ & $\begin{array}{l}1027 \\
84 \cdot 3 \\
0.02\end{array}$ & $\begin{array}{l}889 \\
75 \cdot 9 \\
0 \cdot 13\end{array}$ \\
\hline $\begin{array}{l}\text { Pigf: } \\
\text { Exposed (n) } \\
\text { Exposed (\%) }\end{array}$ & $\begin{array}{l}935 \\
27 \cdot 1\end{array}$ & $\begin{array}{l}1402 \\
54 \cdot 1\end{array}$ & $\begin{array}{l}70 \\
13.9\end{array}$ & $\begin{array}{l}125 \\
34 \cdot 2\end{array}$ & $\begin{array}{l}256 \\
14 \cdot 8\end{array}$ & $\begin{array}{l}592 \\
56 \cdot 2\end{array}$ & $\begin{array}{l}609 \\
50 \cdot 0\end{array}$ & $\begin{array}{l}685 \\
58 \cdot 5\end{array}$ \\
\hline $\begin{array}{l}\text { F/PP: } \\
\text { Exposed (n) } \\
\text { Exposed (\%) } \\
\text { Median AIE (ppm) } \\
\text { F/NPP: }\end{array}$ & $\begin{array}{c}2635 \\
76 \cdot 9 \\
0 \cdot 07\end{array}$ & $\begin{array}{c}1844 \\
71 \cdot 2 \\
0 \cdot 19\end{array}$ & $\begin{array}{c}379 \\
75 \cdot 2 \\
0 \cdot 02\end{array}$ & $\begin{array}{l}239 \\
65 \cdot 3 \\
0 \cdot 14\end{array}$ & $\begin{array}{c}1532 \\
88 \cdot 2 \\
0 \cdot 02\end{array}$ & $\begin{array}{l}876 \\
83 \cdot 2 \\
0 \cdot 19\end{array}$ & $\begin{array}{l}751 \\
61 \cdot 7 \\
0 \cdot 20\end{array}$ & $\begin{array}{l}729 \\
62 \cdot 2 \\
0 \cdot 20\end{array}$ \\
\hline $\begin{array}{l}\text { Exposed (n) } \\
\text { Exposed (\%) } \\
\text { Median AIE (ppm) }\end{array}$ & $\begin{array}{c}2880 \\
83 \cdot 5 \\
0.07\end{array}$ & $\begin{array}{c}2017 \\
77 \cdot 9 \\
0 \cdot 17\end{array}$ & $\begin{array}{l}378 \\
75 \cdot 0 \\
0 \cdot 02\end{array}$ & $\begin{array}{l}252 \\
68 \cdot 8 \\
0 \cdot 13\end{array}$ & $\begin{array}{l}1565 \\
90 \cdot 6 \\
0 \cdot 02\end{array}$ & $\begin{array}{l}919 \\
87 \cdot 3 \\
0 \cdot 17\end{array}$ & $\begin{array}{c}937 \\
76 \cdot 9 \\
0 \cdot 20\end{array}$ & $\begin{array}{c}846 \\
72 \cdot 2 \\
0 \cdot 19\end{array}$ \\
\hline $\begin{array}{l}\text { F/Pig: } \\
\text { Exposed (n) } \\
\text { Exposed (\%) } \\
\text { Median AIE (ppm) }\end{array}$ & $\begin{array}{c}868 \\
25 \cdot 2 \\
0 \cdot 20\end{array}$ & $\begin{array}{c}1293 \\
49 \cdot 9 \\
0 \cdot 20\end{array}$ & $\begin{array}{l}58 \\
11 \cdot 5 \\
0 \cdot 20\end{array}$ & $\begin{array}{c}105 \\
28 \cdot 7 \\
0 \cdot 20\end{array}$ & $\begin{array}{c}249 \\
14 \cdot 4 \\
0 \cdot 46\end{array}$ & $\begin{array}{c}559 \\
53 \cdot 1 \\
0 \cdot 21\end{array}$ & $\begin{array}{c}561 \\
46 \cdot 1 \\
0 \cdot 20\end{array}$ & $\begin{array}{c}629 \\
53 \cdot 7 \\
0 \cdot 20\end{array}$ \\
\hline $\begin{array}{l}\text { F > } 0.2 \text { ppm } \neq: \\
\text { Exposed (n) } \\
\text { Exposed (\%) } \\
\text { F > } 0.7 \text { ppm } \neq:\end{array}$ & $\begin{array}{r}1547 \\
44.9\end{array}$ & $\begin{array}{l}1703 \\
65 \cdot 8\end{array}$ & $\begin{array}{l}196 \\
38 \cdot 9\end{array}$ & $\begin{array}{l}184 \\
50 \cdot 3\end{array}$ & $\begin{array}{l}621 \\
40 \cdot 0\end{array}$ & $\begin{array}{l}780 \\
74 \cdot 1\end{array}$ & $\begin{array}{l}730 \\
59 \cdot 9\end{array}$ & $\begin{array}{l}739 \\
63 \cdot 1\end{array}$ \\
\hline $\begin{array}{l}\text { Exposed (n) } \\
\text { Exposed (\%) }\end{array}$ & $\begin{array}{l}328 \\
9 \cdot 5\end{array}$ & $\begin{array}{l}837 \\
32 \cdot 3\end{array}$ & $\begin{array}{l}59 \\
11 \cdot 7\end{array}$ & $\begin{array}{l}69 \\
18 \cdot 9\end{array}$ & $\begin{array}{l}180 \\
10 \cdot 4\end{array}$ & $\begin{array}{l}474 \\
45 \cdot 0\end{array}$ & $\begin{array}{l}89 \\
7 \cdot 3\end{array}$ & $\begin{array}{l}294 \\
25 \cdot 1\end{array}$ \\
\hline
\end{tabular}

$\star$ Based on exposed jobs only

†See appendix $C$ for definitions of variables.

AIE not computed for this qualitative variable.

STW = short term worker (employed < 1 year); LTW = long term worker (employed $\geqslant 1$ year). 
Table 3 Observed deaths and SMRs for selected causes of death among white male workers and three external comparison populations

\begin{tabular}{|c|c|c|c|c|}
\hline \multirow[b]{2}{*}{ Cause of death (ICD-8) } & \multicolumn{4}{|l|}{$S M R$} \\
\hline & Observed & US & $C T$ & County \\
\hline All caused (000-999) & 1225 & $107^{\star}$ & $117^{\star \star}$ & $114^{\star \star}$ \\
\hline All malignant neoplasms $(140-209)$ & 305 & 110 & 108 & 105 \\
\hline Buccal cavity $(140-145)$ & 6 & 131 & 100 & 104 \\
\hline Oropharynx (146) & 2 & 184 & 136 & 122 \\
\hline Nasopharynx (147) & 4 & $533^{\star}$ & $547^{\star}$ & $550^{\star}$ \\
\hline Hypopharynx (148) & 1 & 141 & 106 & 82 \\
\hline Digestive system (150-159) & 75 & 102 & 90 & 89 \\
\hline Respiratory system (160-163) & 121 & $122^{\star}$ & $134^{\star \star}$ & $128^{\star \star}$ \\
\hline Sinonasal (160 & 2 & 381 & 522 & 372 \\
\hline Larynx (161) & 6 & 147 & 137 & 154 \\
\hline Bronchus, trachea, lung (162) & 113 & 120 & $133^{\star \star}$ & $127^{\star}$ \\
\hline Prostate (185) & 16 & 102 & 100 & 100 \\
\hline Kidney $(189 \cdot 0-189 \cdot 2)$ & 9 & 127 & 122 & 112 \\
\hline \multicolumn{5}{|l|}{ Bladder and other urinary organs } \\
\hline$(188,189.9)$ & 7 & 97 & 89 & 86 \\
\hline \multicolumn{5}{|l|}{ Melanoma of skin $(172 \cdot 0-172 \cdot 4$, } \\
\hline $172 \cdot 6-172 \cdot 9)$ & 7 & 154 & 148 & 160 \\
\hline Central nervous system (191-192) & 15 & 159 & 166 & 170 \\
\hline All lymphopoietic tissue (200-209) & 25 & 89 & 89 & 91 \\
\hline Cerebrovascular disease $(430-438)$ & 64 & 98 & 110 & 111 \\
\hline \multicolumn{5}{|l|}{ All heart disease $(390-398,400 \cdot 1,400 \cdot 9$, } \\
\hline \\
\hline$(460-519)$ & 58 & 85 & 102 & 104 \\
\hline Cirrhosis of liver (571) & 38 & 112 & 110 & 113 \\
\hline Accidents (800-949) & 60 & $78^{\star}$ & 120 & 126 \\
\hline Suicides $(950-959)$ & 33 & 114 & $150^{\star}$ & $159^{\star}$ \\
\hline Unknown causes (in all causes only) & 70 & & & \\
\hline
\end{tabular}

$\star P<0.05 ; \star \star P<<0.01$.

†Based on 1945-84 for cancer mortality (6039 at risk, 146297 person-years) and 1960-84 for total and non-malignant disease mortality (5748 at risk, 110465 person-years).

US = United States; CT = Connecticut.

There was a high degree of association between exposures to formaldehyde and product particulates, and formaldehyde and nonproduct particulates for the total cohort and for short and long term workers considered separately. Very few person-years were contributed by workers exposed to formaldehyde who were never exposed to product particulates or non-product particulates and very few person-years were contributed by workers exposed to product particulates or non-product particulates who were never exposed to formaldehyde. In contrast, $51.5 \%$ of the person-years among all white men were contributed by workers exposed to formaldehyde who were never exposed to pigment, but even here only $0.8 \%$ of the person-years were contributed by those exposed to pigment who were never exposed to formaldehyde. When formaldehyde exposures were restricted to $\geqslant 0.2 \mathrm{ppm}$ and $\geqslant 0.7 \mathrm{ppm}$ an appreciable percentage of person-years (between $28 \%$ and $66 \%$ ) came from workers exposed to product particulates or non-product particulates or both who were never exposed to $\geqslant 0.2$ or $0.7 \mathrm{ppm}$ formaldehyde. Almost all of the workers exposed to pigment were exposed to $\geqslant 0.2 \mathrm{ppm}$ formaldehyde, indicating that exposure to pigment is associated with high formaldehyde exposures.

\section{DESCRIPTIVE MORTALITY ANALYSES}

Table 3 shows the SMRs for white men for selected causes of death based on the United States, Connecticut, and local county rates. For the 70 dead workers for whom death certificates could not be located, deaths are counted only under mortality for all causes and unknown causes (ICD-8 999.9). Thus, cause specific SMRs in table 3 are slightly understated and should probably be multiplied by a factor of $1225 / 1155=1.06$.

Table 3 shows a significantly increased
SMR for total mortality based on United States, Connecticut, or local two county rates with the highest SMRs occurring relative to the state and local populations. In fact, the regional comparisons produced higher SMRs for several of the non-malignant disease categories examined, indicating that these regional death rates were lower than those for the total United States. The opposite pattern is found for the category all malignant neoplasms and for several of the site specific cancer categories examined. Based on the regional comparisons, significantly increased SMRs were found for nasopharyngeal cancer and cancers of the respiratory system and the subcategory, bronchus, trachea, lung. The excess of nasopharyngeal cancer is based on the same four index cases identified previously in the National Cancer Institute study. ${ }^{1}$ Table 3 also shows excess mortality for cancers of the buccal cavity, oropharynx, kidney, skin, and central nervous system, although these were not significant. In the mortality tables that follow, SMRs are based exclusively on the local two county rates, which probably provide the best available adjustment for social, economic, ethnic, and lifestyle factors related to disease for these workers. Although not shown, the mortality experiences of Wallingford non-white male and white female workers were unremarkable and show no significant excesses in total or cause specific mortality and no cases of nasopharyngeal cancer.

Table 4 shows SMRs for selected causes of death for white men by term of employment and year of hire. Short term workers generally had a less favourable total and cause specific mortality experience than their longer term counterparts. For the total cohort, short term workers had significant excesses in total mortality and mortality due to ischaemic heart disease and non-malignant respiratory disease, whereas long term workers had corresponding mortality experiences only slightly higher than the white men of the local two county area. The short term workers account for most of the total and site specific cancer excesses for the total white male cohort (table 3). Among short term workers, significant excesses of site specific cancers were found for the lung, melanoma of the skin, and the central nervous system; no excesses were found among long term workers for melanoma of the skin or cancers of the central nervous system, and the SMR of 119 for lung cancer among long term workers was not significantly increased. The excess of nasopharyngeal cancer (table 3) was maintained among both short and long term workers.

Table 4 also shows that the differential mortality experience of short and long term workers was generally maintained in the three year of hire subcohorts examined, although many of the largest excesses were found among those hired between 1947 and 1956 . For this subcohort, significantly increased SMRs were found among short term workers for nearly all of the cause of death categories examined compared with slightly increased SMRs among the long term workers. For lung cancer, a significant excess was found for the short term workers overall and the 1947-56 
Table 4 Observed deaths and SMRs for selected causes of death among white male short and long term workers by year of hire

\begin{tabular}{|c|c|c|c|c|c|c|c|c|c|}
\hline \multirow[b]{3}{*}{ Cause of death (ICD-8) } & & \multicolumn{8}{|c|}{ Year of hire } \\
\hline & & \multicolumn{2}{|l|}{ Total } & \multicolumn{2}{|c|}{$1941-6$} & \multicolumn{2}{|c|}{$1947-56$} & \multicolumn{2}{|c|}{$\geqslant 1957$} \\
\hline & & OBS & SMR† & $O B S$ & SMRt & OBS & SMRt & OBS & SMR† \\
\hline \multirow[t]{2}{*}{ All causes (000-999) } & STW & 706 & $124^{\star \star}$ & 167 & 105 & 487 & $138^{\star}$ & 52 & 91 \\
\hline & LTW & 519 & 103 & 145 & 103 & 295 & 110 & 79 & 79 \\
\hline \multirow{2}{*}{ All malignant neoplasms (140-209) } & STW & 175 & 115 & 45 & 102 & 119 & $124^{\star}$ & 11 & 92 \\
\hline & LTW & 130 & 95 & 30 & 72 & 76 & 105 & 24 & 101 \\
\hline \multirow[t]{2}{*}{ Buccal cavity and pharynx (140-149) } & STW & 10 & 164 & 0 & - & 9 & $229^{\star}$ & 1 & 218 \\
\hline & LTW & 5 & 91 & 1 & 61 & 3 & 102 & 1 & 107 \\
\hline \multirow[t]{2}{*}{ Nasopharynx (147) } & STW & 2 & 515 & 0 & - & 2 & 768 & 0 & - \\
\hline & LTW & 2 & 596 & 0 & - & 2 & $1049^{\star}$ & 0 & - \\
\hline \multirow[t]{2}{*}{ Bronchus, trachea, lung (160-163) } & STW & 63 & $134^{\star}$ & 15 & 117 & 46 & $151^{\star}$ & 2 & 56 \\
\hline & LTW & 50 & 119 & 12 & 105 & 29 & 126 & 9 & 118 \\
\hline \multirow[t]{2}{*}{ Kidney $(189 \cdot 0-189 \cdot 2)$} & STW & 8 & 185 & 4 & 341 & 4 & 144 & 0 & - \\
\hline & LTW & 1 & 27 & 0 & - & 1 & 50 & 0 & - \\
\hline \multirow{4}{*}{$\begin{array}{l}\text { Melanoma of skin }(172 \cdot 0-172 \cdot 4 \text {, } \\
172 \cdot 6-172 \cdot 9) \\
\text { Central nervous system }(191,192)\end{array}$} & STW & 7 & $288^{\star}$ & 3 & $543^{\star}$ & 3 & 191 & 1 & 317 \\
\hline & LTW & 0 & - & 0 & - & 0 & - & 0 & - \\
\hline & STW & 12 & $245^{\star \star}$ & 2 & 172 & 9 & $283^{\star}$ & 1 & 177 \\
\hline & LTW & 3 & 78 & 1 & 111 & 1 & 46 & 1 & 113 \\
\hline \multirow{2}{*}{ Ischaemic heart disease $(410-414)$} & STW & 228 & $116^{\star}$ & 56 & 96 & 160 & $128^{\star}$ & 12 & 85 \\
\hline & LTW & 186 & 104 & 50 & 94 & 110 & 116 & 26 & 86 \\
\hline \multirow{4}{*}{$\begin{array}{l}\text { Non-malignant respiratory disease } \\
\text { (excluding influenza and pneumonia) } \\
(460-469,475-479,487-519) \\
\text { Unknown causes (in all causes only) }\end{array}$} & STW & 27 & $155^{\star}$ & 6 & 111 & 18 & 168 & 3 & 233 \\
\hline & LTW & 14 & 86 & 10 & 204 & 4 & 45 & 0 & - \\
\hline & STW & 49 & - & - & - & - & - & - & - \\
\hline & LTW & 21 & - & - & - & - & - & - & - \\
\hline
\end{tabular}

$\star \mathrm{P}<0.05 ;{ }^{\star \star} \mathrm{P}<0.01$.

tBased on 1945-84 for cancer mortality and 1960-84 for total and non-malignant disease mortality.

STW = short term worker (employed $<1 \mathrm{y}) ; \mathrm{LTW}=$ long term worker (employed $\geqslant 1 \mathrm{y})$.

year of hire subgroup of short term workers. There was a deficit for the short term workers hired after 1956, based on two deaths. The $18 \%$ to $26 \%$ excesses in the SMRs for lung cancer for the long term workers hired after 1946 were not significant. All four nasopharyngeal cancers occurred among workers hired between 1947 and 1956, resulting in a significant SMR of 1049 for the long term workers and a non-significant increased SMR of 768 for the short term workers.

Table 5 shows selected characteristics and estimated exposures for the four index cases of nasopharyngeal cancer. Exposure to formaldehyde always occurred in the presence of product particulates or non-product particulates, and only case 3 had any appreciable exposure to formaldehyde. None of the cases had any exposure to pigment.

\section{ANALYSIS OF COHORT DATA UNIQUE TO THE PRESENT STUDY}

For the combined data not from the National Cancer Institute white male cohort, table 6 shows the SMRs for selected malignant respiratory disease categories for the 1966-84 fol- low up period. The data not from the National Cancer Institute study contributed two of the six cancers of the buccal cavity, one of the two sinonasal cancers, and 27 of the 113 lung cancers found among the total white male cohort. Based on local county rates, the findings for buccal cavity and lung cancer represent deficits in mortality, whereas the one sinonasal cancer death represents a nonsignificant $7 \cdot 28$-fold excess in mortality. The data not from the National Cancer Institute study yielded no additional nasopharyngeal cancer deaths compared with 0.20 deaths expected.

POISSON REGRESSION ANALYSIS OF RATES AND SMRS FOR LUNG CANCER

Table 7 shows the Poisson regression models relating mortality from lung cancer to duration of exposure to formaldehyde $(\geqslant 0.2 \mathrm{ppm}$ ) for the total cohort and for the short and long term workers considered separately. Table 7 shows for each exposure category the observed number of lung cancer deaths, the externally adjusted SMR, the unadjusted ratio of SMRs (category specific SMR to the baseline cate-

Table 5 Selected characteristics of deaths due to nasopharyngeal cancer (all white men)

\begin{tabular}{|c|c|c|c|c|c|c|c|c|c|c|c|c|c|}
\hline \multirow[b]{2}{*}{ Case No. } & \multicolumn{6}{|c|}{ Estimated exposure levels* } & \multirow[b]{2}{*}{$\begin{array}{l}\text { Year of } \\
\text { hire }\end{array}$} & \multirow[b]{2}{*}{$\begin{array}{l}\text { Year of } \\
\text { term }\end{array}$} & \multirow[b]{2}{*}{$\begin{array}{l}\text { Year of } \\
\text { death }\end{array}$} & \multirow{2}{*}{$\begin{array}{l}\text { Age at } \\
\text { death } \\
(y)\end{array}$} & \multirow{2}{*}{$\begin{array}{l}\text { Duration } \\
\text { of employ- } \\
\text { ment } \\
(y)\end{array}$} & \multirow{2}{*}{$\begin{array}{l}\text { Time since } \\
\text { first employ- } \\
\text { ment } \\
\text { (y) }\end{array}$} & \multirow[b]{2}{*}{ Underlying cause of death } \\
\hline & $F t \neq$ & PP+S & NPP+S & Pig & $\begin{array}{l}F /(P P \text { or } \\
N P P)+\neq\end{array}$ & F/Pig & & & & & & & \\
\hline 1: & & & & & & & & & & & & & \\
\hline $\begin{array}{l}\text { DUR } \\
\text { TWE } \\
\text { AIE }\end{array}$ & $\begin{array}{l}0.625 \\
0.084 \\
0.134\end{array}$ & $\begin{array}{l}0.625 \\
0.047 \\
0.075\end{array}$ & $\begin{array}{l}0.625 \\
0.084 \\
0.134\end{array}$ & $\begin{array}{l}0 \\
0 \\
0\end{array}$ & $\begin{array}{l}0.625 \\
0.084 \\
0.134\end{array}$ & $\begin{array}{l}0 \\
0 \\
0\end{array}$ & 1950 & 1950 & 1967 & $56 \cdot 6$ & 0.6 & $18 \cdot 0$ & Epidermoid cancer of nasopharynx \\
\hline $\begin{array}{l}\text { DUR } \\
\text { TWE } \\
\text { AIE }\end{array}$ & $\begin{array}{l}0.252 \\
0.007 \\
0.027\end{array}$ & $\begin{array}{l}0.216 \\
0.043 \\
0.200\end{array}$ & $\begin{array}{l}0.252 \\
0.011 \\
0.045\end{array}$ & $\begin{array}{l}0 \\
0 \\
0\end{array}$ & $\begin{array}{l}0.252 \\
0.007 \\
0.027\end{array}$ & $\begin{array}{l}0 \\
0 \\
0\end{array}$ & 1949 & 1950 & 1969 & $42 \cdot 2$ & 0.3 & $19 \cdot 2$ & $\begin{array}{l}\text { Metastatic epidermoid cancer of } \\
\text { nasopharynx }\end{array}$ \\
\hline $\begin{array}{l}\text { DUR } \\
\text { TWE } \\
\text { AIE }\end{array}$ & $\begin{array}{r}17.879 \\
10.821 \\
0.605\end{array}$ & $\begin{array}{r}16 \cdot 153 \\
3 \cdot 007 \\
0 \cdot 186\end{array}$ & $\begin{array}{r}17 \cdot 879 \\
46 \cdot 423 \\
2 \cdot 596\end{array}$ & $\begin{array}{l}0 \\
0 \\
0\end{array}$ & $\begin{array}{r}17 \cdot 879 \\
10 \cdot 821 \\
0 \cdot 605\end{array}$ & $\begin{array}{l}0 \\
0 \\
0\end{array}$ & 1955 & 1973 & 1976 & $64 \cdot 2$ & $17 \cdot 9$ & $21 \cdot 3$ & Carcinoma of nasopharynx \\
\hline $\begin{array}{l}\text { DUR } \\
\text { TWE } \\
\text { AIE }\end{array}$ & $\begin{array}{l}4 \cdot 279 \\
0 \cdot 684 \\
0 \cdot 160\end{array}$ & $\begin{array}{l}4 \cdot 088 \\
0 \cdot 417 \\
0 \cdot 102\end{array}$ & $\begin{array}{l}3.463 \\
0.538 \\
0.155\end{array}$ & $\begin{array}{l}0 \\
0 \\
0\end{array}$ & $\begin{array}{l}4 \cdot 279 \\
0 \cdot 684 \\
0 \cdot 160\end{array}$ & $\begin{array}{l}0 \\
0 \\
0\end{array}$ & 1951 & 1955 & 1977 & $52 \cdot 4$ & $4 \cdot 3$ & $25 \cdot 5$ & $\begin{array}{l}\text { Nasopharyngeal carcinoma with } \\
\text { regional and cranial metastases }\end{array}$ \\
\hline
\end{tabular}

* See appendix $\mathrm{C}$ for definitions of variables.

†DUR (y).

†TWR (y).

fTWE (ppm-y), AIE (ppm).
ITWE (mg/m $\left.\mathrm{m}^{3}-\mathrm{y}\right), \operatorname{AIE}\left(\mathrm{mg} / \mathrm{m}^{3}\right)$. 
Table 6 Observed and expected deaths and SMRs for selected cancer sites for white male cohort data not from the National Cancer Institute study* 1966-84, local two county comparison

\begin{tabular}{lccc}
\hline Cause of death (ICD-8) & Observed & Expected & SMR \\
\hline Buccal cavity and pharynx (140-149) & 2 & 2.95 & 68 \\
Nasopharyngeal (147) & 0 & $0 \cdot 20$ & - \\
Sinonasal (160) & 1 & $0 \cdot 14$ & 728 \\
Bronchus, trachea, lung (162) & 27 & 28.32 & 95
\end{tabular}

*Workers hired 1966-84 and workers hired before 1 January 1966 who were alive as of 1 January 1980. at $\geqslant 0.2 \mathrm{ppm}$. For the total cohort, significant heterogeneity in the estimated risk ratios was found for both the rates and the SMRs, with estimated risk ratios of $\geqslant 1.5$ for all exposure categories above the baseline. Although there was a significant linear trend component to these estimates, the risk ratios did not increase monotonically with increasing exposure. The short term workers show a highly significant positive gradient in estimated risk ratios for both rates and SMRs. The estimated risk ratios of 6.03 and 5.37 based on the SMRs and rates, respectively, for short term workers employed for half to one year in jobs with exposure to formaldehydes of at least $0.2 \mathrm{ppm}$ were based on seven deaths. Among the long term workers, neither the heterogeneity nor the linear trend was significant, and the estimated risk ratios for the $0.5-5.0$ exposure category were close to baseline levels.

Table 8 presents risk ratio estimates for several measures of average intensity of exposure

Table 7 Summary of unadjusted and adjusted mortality measures for duration (y) of exposure to formaldehyde $\geqslant 0.2 \mathrm{ppm}$, cancer of the lung in the Wallingford white male cohort, 1945-84 by term of employment

\begin{tabular}{|c|c|c|c|c|c|c|c|c|c|}
\hline \multirow[b]{2}{*}{$\begin{array}{l}\text { Duration of exposure } \\
\text { to formaldehyde } \\
(\geqslant 0.2 \mathrm{ppm})\end{array}$} & \multirow[b]{2}{*}{$\begin{array}{l}\text { Observed } \\
\text { deaths }\end{array}$} & \multirow[b]{2}{*}{$S M R^{*}$} & \multirow[b]{2}{*}{$\begin{array}{l}\text { Unadjusted } \\
\text { ratiot of } \\
\text { SMRs }\end{array}$} & \multicolumn{6}{|c|}{ Adjusted estimates of risk ratio } \\
\hline & & & & $\begin{array}{l}S M R \\
\text { based\# }\end{array}$ & $\begin{array}{l}\text { Global } \\
P \text { value }\end{array}$ & $\begin{array}{l}\text { Trend } \\
\text { P value }\end{array}$ & $\begin{array}{l}\text { Cohort } \\
\text { rate } \\
\text { baseds }\end{array}$ & $\begin{array}{l}\text { Global } \\
P \text { value }\end{array}$ & $\begin{array}{l}\text { Trend } \\
\text { P value }\end{array}$ \\
\hline $\begin{array}{l}\text { Total cohort: } \\
0 \\
<0.5 \\
0.5-4.9 \\
\geqslant 5\end{array}$ & $\begin{array}{l}41 \\
34 \\
22 \\
16\end{array}$ & $\begin{array}{r}93 \\
166 \\
145 \\
170\end{array}$ & $\begin{array}{l}1.00 \\
1.78 \\
1.56 \\
1.83\end{array}$ & $\begin{array}{l}1 \cdot 00 \\
1 \cdot 74 \\
1 \cdot 57 \\
1 \cdot 80\end{array}$ & 0.05 & 0.02 & $\begin{array}{l}1 \cdot 00 \\
1 \cdot 64 \\
1 \cdot 54 \\
2 \cdot 21\end{array}$ & 0.03 & 0.01 \\
\hline $\begin{array}{l}\text { Short term workers: } \\
0 \\
<0.5 \\
0.5-1.0\end{array}$ & $\begin{array}{r}27 \\
29 \\
7\end{array}$ & $\begin{array}{r}95 \\
169 \\
530\end{array}$ & $\begin{array}{l}1.00 \\
1 \cdot 78 \\
5 \cdot 58\end{array}$ & $\begin{array}{l}1 \cdot 00 \\
1 \cdot 81 \\
6 \cdot 03\end{array}$ & $<0.01$ & $<0.01$ & $\begin{array}{l}1 \cdot 00 \\
1 \cdot 85 \\
5 \cdot 37\end{array}$ & $<0.01$ & $<0.01$ \\
\hline $\begin{array}{l}\text { Long term workers: } \\
\quad 0 \\
<0.5 \\
0.5-4.9 \\
\geqslant 5.0\end{array}$ & $\begin{array}{r}14 \\
5 \\
15 \\
16\end{array}$ & $\begin{array}{r}90 \\
149 \\
108 \\
170\end{array}$ & $\begin{array}{l}1.00 \\
1.66 \\
1.20 \\
1.89\end{array}$ & $\begin{array}{l}1 \cdot 00 \\
1 \cdot 65 \\
1 \cdot 18 \\
1 \cdot 81\end{array}$ & 0.42 & $0 \cdot 18$ & $\begin{array}{l}1.00 \\
1.48 \\
1.01 \\
1.96\end{array}$ & $0 \cdot 25$ & $0 \cdot 17$ \\
\hline
\end{tabular}

«SMR internally adjusted for age group and calendar time period.

†Relative to baseline category.

fAll models adjusted for year of hire and time since first employment in Poisson regression.

SAll models adjusted for age, time period, year of hire and time since first employment in Poisson regression.

Table 8 Summary of unadjusted and adjusted mortality measures for selected exposure models, cancer of the lung in the short and long term Wallingford white male cohort, 1945-84

\begin{tabular}{|c|c|c|c|c|c|c|c|}
\hline \multirow[b]{2}{*}{ Exposure variable ${ }^{\star}$} & \multirow[b]{2}{*}{$\begin{array}{l}\text { Observed } \\
\text { deaths }\end{array}$} & \multirow[b]{2}{*}{ SMR† } & \multirow[b]{2}{*}{$\begin{array}{l}\text { Unadjusted } \\
\text { ratio } \neq \text { of } \\
\text { SMRs }\end{array}$} & \multicolumn{4}{|c|}{ Adjusted estimates of risk ratio } \\
\hline & & & & $\begin{array}{l}\text { SMR } \\
\text { based }\end{array}$ & $\begin{array}{l}\text { Global } \\
\text { P value }\end{array}$ & $\begin{array}{l}\text { Cohort } \\
\text { rate } \\
\text { based }\end{array}$ & $\begin{array}{l}\text { Global } \\
\text { Pvalue }\end{array}$ \\
\hline \multicolumn{8}{|l|}{$\begin{array}{l}\text { Short term workers: } \\
\text { AIE }(\mathbf{F}) \text { : }\end{array}$} \\
\hline & 30 & 96 & 1.00 & & $<0.01$ & & $<0.01$ \\
\hline$\geqslant 0 \cdot 1$ & 33 & 211 & $2 \cdot 20$ & $\begin{array}{l}1 \cdot 00 \\
2 \cdot 25\end{array}$ & & $\begin{array}{l}1 \cdot 00 \\
2 \cdot 23\end{array}$ & \\
\hline AIE (F/PP): & & & & & $<0.01$ & & $<0.01$ \\
\hline $\begin{array}{l}<0.1 \\
\geqslant 0.1\end{array}$ & $\begin{array}{l}31 \\
32\end{array}$ & $\begin{array}{r}98 \\
210\end{array}$ & $\begin{array}{l}1 \cdot 00 \\
2 \cdot 14\end{array}$ & $\begin{array}{l}1 \cdot 00 \\
2 \cdot 17\end{array}$ & & $\begin{array}{l}1 \cdot 00 \\
2 \cdot 17\end{array}$ & \\
\hline AIE (F/NPP): & & & & & $<0.01$ & & $<0.01$ \\
\hline $\begin{array}{l}<0.1 \\
\geqslant 0.1\end{array}$ & $\begin{array}{l}31 \\
32\end{array}$ & $\begin{array}{l}102 \\
208\end{array}$ & $\begin{array}{l}1 \cdot 00 \\
2 \cdot 04\end{array}$ & $\begin{array}{l}1 \cdot 00 \\
2 \cdot 16\end{array}$ & & $\begin{array}{l}1 \cdot 00 \\
2 \cdot 13\end{array}$ & \\
\hline AIE (F/Pig): & & & & & 0.07 & & 0.09 \\
\hline $\begin{array}{l}<0.1 \\
\geqslant 0.1\end{array}$ & $\begin{array}{l}49 \\
14\end{array}$ & $\begin{array}{l}122 \\
209\end{array}$ & $\begin{array}{l}1 \cdot 00 \\
1 \cdot 71\end{array}$ & $\begin{array}{l}1.00 \\
1.81\end{array}$ & & $\begin{array}{l}1.00 \\
1.75\end{array}$ & \\
\hline Long term workers: & & & & & & & \\
\hline $\begin{array}{r}\text { AIE (F): } \\
<0 \cdot 1\end{array}$ & & & & & 0.79 & & 0.85 \\
\hline $\begin{array}{l}<0.1 \\
\geqslant 0.1\end{array}$ & $\begin{array}{l}23 \\
27\end{array}$ & $\begin{array}{l}106 \\
132\end{array}$ & $\begin{array}{l}1.00 \\
1 \cdot 24\end{array}$ & $\begin{array}{l}1.00 \\
1.09\end{array}$ & & $\begin{array}{l}1.00 \\
1.06\end{array}$ & \\
\hline AIE (F/PP): & & & & & 0.72 & & 0.83 \\
\hline $\begin{array}{l}<0.1 \\
\geqslant 0.1\end{array}$ & $\begin{array}{l}21 \\
29\end{array}$ & $\begin{array}{l}102 \\
135\end{array}$ & $\begin{array}{l}1.00 \\
1.32\end{array}$ & $\begin{array}{l}1.00 \\
1.13\end{array}$ & & $\begin{array}{l}1.00 \\
1.08\end{array}$ & \\
\hline AIE (F/NPP): & & & & & $0 \cdot 16$ & & 0.24 \\
\hline $\begin{array}{l}<0.1 \\
\geqslant 0.1\end{array}$ & $\begin{array}{l}19 \\
31\end{array}$ & $\begin{array}{r}94 \\
148\end{array}$ & $\begin{array}{l}1.00 \\
1.57\end{array}$ & $\begin{array}{l}1.00 \\
1.64\end{array}$ & & $\begin{array}{l}1.00 \\
1.49\end{array}$ & \\
\hline AIE (F/Pig): & & & & & $0 \cdot 16$ & & $0 \cdot 23$ \\
\hline $\begin{array}{l}<0.1 \\
\geqslant 0.1\end{array}$ & $\begin{array}{l}25 \\
25\end{array}$ & $\begin{array}{l}100 \\
146\end{array}$ & $\begin{array}{l}1.00 \\
1.46\end{array}$ & $\begin{array}{l}1.00 \\
1.65\end{array}$ & & $\begin{array}{l}1.00 \\
1.53\end{array}$ & \\
\hline
\end{tabular}

${ }^{\star}$ Refer to appendix $\mathrm{C}$ for definitions of variables.

†SMR internally adjusted for age group and calendar period.

$¥$ Relative to baseline category.

fAll models adjusted for year of hire and time since first employment in Poisson regression.

TAll models adjusted for age, time period, year of hire and time since first employment in Poisson regression. 
Table 9 Summary of Poisson regression modelling of SMRs and cohort rates for lung cancer

\begin{tabular}{|c|c|c|c|c|c|c|}
\hline \multirow[b]{2}{*}{ Variable } & \multicolumn{2}{|l|}{ All workers } & \multicolumn{2}{|c|}{ Long term workers } & \multicolumn{2}{|l|}{ Short term workers } \\
\hline & $S M R$ & Cohort rate & $S M R$ & Cohort rate & $S M R$ & Cohort rate \\
\hline Year of hire & NS & $G=0.05$ & NS & NS & - & - \\
\hline Duration of employment & NS & NS & NS & NS & - & - \\
\hline Time since first employment & NS & $\mathrm{G}=0.01$ & NS & NS & - & - \\
\hline DUR (F)t & NS & NS & NS & NS & - & - \\
\hline DUR $(F \geqslant 0.2 \mathrm{ppm}) \dagger$ & $G=0.05, T=0.02$ & $G=0.03, T=0.01$ & NS & NS & $G<0.01, T<0.01$ & $\mathrm{G}<0.01, \mathrm{~T}<0.01$ \\
\hline DUR $(F \geqslant 0.7 \mathrm{ppm}) \dagger$ & NS & NS & NS & NS & - & - \\
\hline DUR (PP)† & NS & $T=0.08$ & NS & $T=0 \cdot 10$ & - & - \\
\hline DUR (NPP)† & NS & NS & NS & NS & - & - \\
\hline DUR (Pig) $\dagger$ & $G=0.02$ & $\mathrm{G}=0.05$ & NS & NS & - & - \\
\hline TWE $(F) \dagger$ & NS & NS & NS & NS & - & - \\
\hline TWE $(\mathrm{F} / \mathrm{PP}) \dagger$ & NS & $T=0.08$ & NS & NS & - & - \\
\hline TWE (F/NPP) † & NS & NS & NS & NS & - & - \\
\hline TWE (F/Pig)t & NS & NS & NS & NS & - & - \\
\hline TWE (F)/TWE (PP) & NS & NS & NS & $G=0 \cdot 10$ & - & - \\
\hline TWE (F)/TWE (NPP) & NS & NS & $G=0.09$ & $\mathrm{G}=0.05$ & - & - \\
\hline TWE (F)/DUR (Pig) & NS & NS & $\mathrm{G}=0.09$ & $\mathrm{G}=0.07$ & - & - \\
\hline TWE (PP)/TWE (F) & NS & NS & NS & NS & - & - \\
\hline TWE (NPP)/TWE (F) & NS & NS & NS & NS & - & 一 \\
\hline DUR (Pig)/TWE (F) & $\mathrm{G}=0.02$ & $\mathrm{G}=0.03$ & NS & NS & - & - \\
\hline AIE $(F)$ & $\mathrm{G}<0.01$ & $\mathrm{G}=0.01$ & NS & NS & $G<0.01$ & $\mathrm{G}<0.01$ \\
\hline $\mathrm{AIE}(\mathrm{F} / \mathrm{PP})$ & $G<0.01$ & $G=0.01$ & NS & NS & $G<0.01$ & $G<0.01$ \\
\hline AIE (F/NPP) & $G<0.01$ & $G<0.01$ & NS & NS & $G<0.01$ & $\mathrm{G}<0.01$ \\
\hline $\mathrm{AIE}$ (F/Pig) & $G=0.03$ & $\mathrm{G}=0.05$ & NS & NS & $G=0.07$ & $G=0.09$ \\
\hline
\end{tabular}

$\star$ Refer to appendix $\mathrm{C}$ for definitions of variables.

$t$ Trend test performed for this variable.

$\mathrm{G}=$ Global test $\mathrm{P}$ value; $\mathrm{T}=$ trend test $\mathrm{P}$ value; $\mathrm{NS}=$ not significant at $0 \cdot 10$ level.

separately for short and for long term workers. Again, in contrast to long term workers, short term workers show larger and significant estimated risk ratios for SMRs and rates for those exposed to the baseline categor $<0.1 \mathrm{ppm}$ compared with those exposed to $\geqslant 0 \cdot 1 \mathrm{ppm}$ for intensity of exposure to formaldehyde, intensity of exposure to formaldehyde and product particulates, and intensity of exposure to formaldehyde and non-product particulates. The estimated risk ratios were consistently more than doubled for the short term workers exposed at more than $0.1 \mathrm{ppm}$ to these agents. Risk ratios of 1.81 and 1.75 were estimated for short term workers exposed to intensities of exposure to formaldehyde and pigment $\geqslant 0 \cdot 1$ ppm based on SMRs $(P=0.07)$ and rates $(P$ $=0.09$ ), respectively; the corresponding estimates of 1.65 and 1.53 for the long term workers were not significantly increased $(P>0.15$ for each).

Table 9 presents a summary of our Poisson regression modelling of lung cancer SMRs and rates for this Wallingford cohort. To decide which adjustment factors to include in subsequent models involving the exposure variables, the SMRs and cohort rates were first modelled as a function of the year of hire, duration of employment, and time since first employment. For the total white male cohort, there was significant heterogeneity in the cohort rates for year of hire (with estimated risk ratios of 1.0 , 1.45 , and 0.71 for the year of hire categories 1941-6, 1947-56, and 1957-84, respectively). Significantly increased risk was associated with increasing time since first employment, with estimated risk ratios of $1 \cdot 0,2 \cdot 21$, and 3.99 for the categories $<20,20-9$, and $\geqslant 30$ years, respectively. None of these effects were even of marginal significance in the models for the SMRs or the long term workers. With the exception of the models involving two time dependent exposure measures, all subsequent models were adjusted for both year of hire and time since first employment.

Next, duration of exposure to each agent and time weighted exposure to formaldehyde with and without consideration of each coexposure were modelled separately. Table 7 has already shown the results for duration of exposure to $\geqslant 0.2 \mathrm{ppm}$ formaldehyde. For the total white male cohort, significant heterogeneity was found in both the SMRs and the cohort rates as a function of duration of exposure to pigment, with estimated risk ratios of $1.0,1.99$, and 0.98 for the SMRs for a duration of exposure to pigment of $0,<0.5$, and $\geqslant 0.5$ years, respectively, and corresponding risk ratios for the cohort rates of $1 \cdot 0,1 \cdot 87$, and $1 \cdot 08$. A trend of borderline significance was found in the cohort rates for duration of exposure to product particulates and time weighted exposure to formaldehyde and product particulates, with estimated risk ratios of $1 \cdot 0,1 \cdot 1,1 \cdot 27$, and $1 \cdot 74$ for duration of exposure to product particulates, and estimated risk ratios of $1.0,1.04,1.45$, and 1.55 for time weighted exposure to formaldehyde and product particulates. A similar trend with duration of exposure to product particulates was also found in the cohort rates for the long term workers, with estimated risk ratios of $1 \cdot 0,1 \cdot 15$, 1.11 , and 1.83 for duration of exposure to product particulates of $0,<0.5,0.5-4.9$, and $\geqslant 5$ years, respectively.

In the next set of models, time weighted exposure to formaldehyde was modelled jointly with time weighted exposure to each of the other coexposures in separate models. The $P$ values for this set of models refer to the first variable listed. For example, for long term workers and time weighted exposure to formaldehyde and time weighted exposure to product particulates, $G=0 \cdot 10$ is the global $P$ value for time weighted exposure to formaldehyde given that time weighted exposure to product particulates is in the model. This analysis was adjusted for year of hire but not for time since first exposure. Among the long term workers, there was some evidence of heterogeneity in the cohort rates as a function of time weighted exposure to formaldehyde when adjusted for time weighted exposure to product particulates, for time weighted exposure to non-product particulates, and for 
duration of exposure to pigment $(P \leqslant 0 \cdot 10$ for each). None of these effects increased monotonically with increasing time weighted exposure to formaldehyde. For example, when adjusted for time weighted exposure to product particulates, the estimated risk ratios for the long term workers at the four levels of time weighted exposure to formaldehyde $(0,<0.05,0.05-1$, and $>1$ ppm-y) were $1 \cdot 0,2 \cdot 58,0 \cdot 81$ and $1 \cdot 34$, respectively. The corresponding estimates were $1 \cdot 0,5 \cdot 36,2 \cdot 30$, and 4.67 adjusted for time weighted exposure to non-product particulates, and $1.0,2.64$, 0.99 , and 1.97 adjusted for duration of exposure to pigment. Similar results were obtained for the SMR models for the long term workers, except that the heterogeneity with time weighted exposure to formaldehyde when adjusted for time weighted exposure to product particulates was not significant at the $0 \cdot 10$ level.

Table 9 also shows the $P$ values for each of the coexposures adjusted for time weighted exposure to formaldehyde. Significant heterogeneity in the SMRs and cohort rates was found only for duration of exposure to pigment in the total white male cohort. The estimated risks were similar to those given earlier for duration of exposure to pigment without adjustment for time weighted exposure to formaldehyde, with almost twofold increases seen for duration of exposure to pigment of $<0.5$ years relative to the 0 and $\geqslant 0.5$ year categories. The last section of this table summarises the results given in table 8 .

Poisson regression modelling was performed on short term workers only for those models where a significant main effect of exposure to formaldehyde was found in the total cohort (duration of exposure to $\geqslant 0.2 \mathrm{ppm}$ formaldehyde, average intensity of exposure to formaldehyde, average intensity of exposure to formaldehyde and to product particulates, average intensity of exposure to formaldehyde and to non-product particulates, and average intensity of exposure to formaldehyde and pigment (the last two columns of table 9)). Virtually all of the significant findings for lung cancer among the total cohort can be attributed to significant findings among the short term workers.

\section{Discussion and conclusions}

Many historical cohort studies, including the one reported here, have shown unusual mortality patterns for non-malignant and malignant disease among short term workers. ${ }^{1533}$ Differential mortality patterns found among short term workers can be due to risks acquired elsewhere-for example-avocations or earlier employment-to non-occupationally related differences in behaviour or lifestyle-for example, tobacco and alcohol consumption-or to occupationally related differences in job type or exposure-for example, newly hired employees assigned to "dirtier", less desirable jobs. ${ }^{34-36}$ For these reasons, very short term workers are frequently excluded from studies of occupational cohorts or else considered separately.

Based on our new exposure assessment of the Wallingford plant, work histories of the short term and long term workers could be compared relative to several measures of exposure to formaldehyde, product particulates, non-product particulates, and pigments. We found little evidence that short term white male workers held different jobs than those who went on to work for longer periods of time in this plant, or that the jobs they held had higher exposures to any of the agents considered. The same conclusion was reached by Stewart et $a l^{15}$ after a similar analysis by Blair et $a l^{1}$ of the cohort data. One exception to this general pattern occurred among workers initially hired between 1947 and 1956. For this subgroup, the median average intensity of exposure to formaldehyde in the presence of pigment exposure was $0.46 \mathrm{ppm}$ for the $14.4 \%$ of exposed short term workers compared with $0.21 \mathrm{ppm}$ for the $53.1 \%$ of exposed long term workers. Significant excesses in mortality for all cancers combined and for many of the specific cancer sites were found for the short term workers in the 1947-56 year of hire subcohort.

Few differences were found between short and long term workers for exposures to the agents considered. Demographic differences between the long term workers and the short term workers were slight: long term workers tended to be born longer ago, hired more recently, and hired at somewhat older ages than the short term workers. Our findings of higher SMRs among short term workers for many categories of disease related to smoking (lung cancer, ischaemic heart disease, and non-malignant respiratory disease) suggest a difference in smoking habits between short and long term workers in the Wallingford cohort. Over $60 \%$ of the short term workers in this cohort were actually employed at this plant for less than three months.

Robins et al $^{12}$ considered whether the slight excesses and the apparent lack of exposureresponse between exposure to formaldehyde and lung cancer in the study of Blair et $a l^{1}$ could be explained by the healthy worker survivor effect, which is defined as the tendency of workers at increased risk of death to end employment early. Based on the proposed Gnull tests, Robins et $a l^{12}$ found no evidence that the healthy worker effect was biasing the findings of Blair et $a l^{1}$ for lung cancer mortality. In the present study, because the occupational exposures for the short term workers seem to be generally similar to those of long term workers, we have no reason to suspect that the healthy worker effect is introducing major biases. However, significant positive effects have been identified for the short term workers in the present study. The presence of a healthy worker effect could mean that we are underestimating the risk associated with exposure among short term workers.

In this update, no additional cases of nasopharyngeal cancer were found in the Wallingford plant cohort despite our independent enumeration of an expanded cohort with an additional five years of follow up. The four cases were the same index cases identified in the original National Cancer Institute study, whose suspected clustering in this one plant 
served as a major impetus for our study. Although these four cases of nasopharyngeal cancer did represent a significant excess greater than fivefold, the very small numbers of deaths from nasopharyngeal cancer precluded a more detailed investigation of possible aetiological factors. Although all four cases had at least some exposure to both formaldehyde and particulates (as did over $80 \%$ of the white male cohort), only one case had any appreciable exposure to formaldehyde. The potential for diagnostic misclassification of nasopharyngeal cancer has been considered elsewhere. ${ }^{37} 38$

A major portion of this investigation was directed at the question of whether the significant $27 \%$ excess in lung cancer mortality among the total white male cohort was in any way related to occupational factors at the Wallingford plant. Our Poisson regression modelling of internal cohort rates and SMRs showed that virtually all of the evidence of a relation between exposure to formaldehyde (with or without coexposures) and lung cancer occurred within the cohort of short term workers. Among the long term workers there was no clear evidence of an association between mortality from lung cancer and any occupational factors with the possible exception of cumulative exposure to formaldehyde when evaluated jointly with each of the three coexposure agents (table 9). Although monotone trends were not found with increasing time weighted exposure to formaldehyde in any of these analyses, consistently greater than twofold risk ratios were found for time weighted exposure to formaldehyde in each category above the baseline when adjusted for time weighted exposure to non-product particulates. The analysis of time weighted exposure to formaldehyde adjusted for time weighted exposure to non-product particulates is sensitive to the collinearity between these two exposures: only $2.3 \%$ of the white male person-years in this study involved exposure to non-product particulates and not to formaldehyde, and $1 \cdot 2 \%$ of the white male person-years involved exposure to formaldehyde but not to non-product particulates.

At least a portion of the non-significant $19 \%$ excess of lung cancer in long term white male workers may be linked to exposures to agents not studied here that were used or produced at the Wallingford plant. Recent reanalyses of the total National Cancer Institute formaldehyde worker cohort, which includes the Wallingford plant, have found significant positive associations between risk of lung cancer and cumulative exposure to formaldehyde in the presence of several other coexposures including antioxidants, hexamethylenetetramine, melamine, phenol, and urea. ${ }^{9-11}$

The composition of this workforce is such that the cohort is relatively uninformative about the risks associated with exposures of long duration as the long term workers comprised only $43 \%$ of the white male cohort. Because less than one third of these long term workers were employed for more than five years in the Wallingford plant, this study lacks power to detect trends with increasing exposure. A plateau effect was found for many of the exposures, with the risk ratios generally increased for levels of exposure above the baseline, but with no apparent trend.

In conclusion, this study provides little evidence that the risk of lung cancer is associated with exposure to formaldehyde alone or in combination with exposures to particulates or pigment among workers employed for at least one year in this plant. The excess risk of lung cancer found in the total white male cohort seems to be primarily a short term worker phenomenon, but the possibility remains that unmeasured occupational or non-occupational factors may have played a part.

\section{Appendix A: Comparison of selected Wallingford cohort data from current study and NCI study}

\begin{tabular}{|c|c|c|}
\hline Characteristic & $\begin{array}{l}\text { Current } \\
\text { study }\end{array}$ & $\begin{array}{l}\text { NCI study } \\
(\text { plant } 1)^{\star}\end{array}$ \\
\hline $\begin{array}{l}\text { Cohort } \\
\text { definition } \\
\text { Cohort size } \\
\text { Primary } \\
\text { analysis } \\
\text { subcohort }\end{array}$ & $\begin{array}{l}\text { All employees } \\
\text { hired 1941-84 } \\
7359 \\
\text { White men, } \\
1945-84 \\
\text { study period }\end{array}$ & $\begin{array}{l}\text { All employees } \\
\text { hired 1940-66 } \\
4389 \\
\text { White men (excluding } \\
\text { unknown job type), } \\
1943-79 \\
\text { study period }\end{array}$ \\
\hline $\begin{array}{l}\text { Subcohort size } \\
\text { Total deaths }\end{array}$ & $\begin{array}{l}6039 \\
1396\end{array}$ & $\begin{array}{l}3659 \\
787\end{array}$ \\
\hline $\begin{array}{l}\text { Lung cancer } \\
\text { deaths }\end{array}$ & 113 & 59 \\
\hline
\end{tabular}

^NCI study data as developed for Marsh et al reanalyses. ${ }^{1011}$

\section{Appendix B: Exposure assignment} procedures used in current study

Given the scarcity of measurements, our initial preference in assigning exposure was to assign exposures strictly on a ranked basis, between background and a highest rank, without attributing a physically meaningful number to each level. Although this approach would have been reasonable, because the National Cancer Institute study had some numbers attached to their estimates, we were concerned that our estimates would seem "less rigorous". Keeping in mind that each estimate is subjective, the details of our process are elucidated below. The estimation process for formaldehyde is detailed; the same procedures were used to estimate the other exposures considered.

There were detailed job assignment and employment sheets for 156 jobs. In these sheets, details of tasks done by the holder of that job title were outlined. Also there were entries for dustiness, noisiness, safety, and similar concerns. These 156 classes and the additional job classes created to classify the job titles that did not fit the original classes are referred to as job numbers. Table B-1 shows the job or task ranking criteria. The exposure assignment precedure based on the attributes listed in the table was first applied to the original job number list, and an exposure rank for each job number was developed. The job titles that appeared in the employment records were culled to extract those that fitted the descriptions of these job numbers exactly. The remaining job titles were then examined to identify similar groups, who were assigned additional job numbers. The plant personnel verified the appropriateness of including each previously unassigned job title into one of these new job numbers. Exposures were assigned to these new job numbers based on the ranking table, and the employment records were culled again. After several iterations of generating new job numbers, less than 20 as yet unclassified job 
Table B-1 Exposure classification levels

\begin{tabular}{|c|c|c|}
\hline Rank & Range (ppm) & Description \\
\hline 0 & $<0.01$ & Background exposure \\
\hline 1 & $0.01-0.05$ & $\begin{array}{l}\text { Mostly background with occasional presence in the } \\
\text { manufacturing areas - for example, supervisor }\end{array}$ \\
\hline 2 & $0.05-0.1$ & $\begin{array}{l}\text { The jobs that dealt with the product end with possibly trace } \\
\text { amount of the pollutant }\end{array}$ \\
\hline 3 & $0 \cdot 1-0 \cdot 5$ & $\begin{array}{l}\text { All jobs in the middle stages of operation with some } \\
\text { potential for high but short duration of exposure to } \\
\text { formaldehyde }\end{array}$ \\
\hline 4 & $0.5-1$ & $\begin{array}{l}\text { Jobs that dealt with pure formaldehyde or slurries } \\
\text { containing formaldehyde only part of the day with } \\
\text { potentially high but short duration of exposure to } \\
\text { formaldehyde several times a day }\end{array}$ \\
\hline 5 & $1-5$ & $\begin{array}{l}\text { Jobs that dealt directly with pure formaldehyde or slurries } \\
\text { containing high formaldehyde concentrations most of the } \\
\text { day and had frequent high but short duration } \\
\text { formaldehyde exposure potential }\end{array}$ \\
\hline 6 & $>5$ & $\begin{array}{l}\text { Jobs that dealt directly with pure formaldehyde or slurries } \\
\text { containing high formaldehyde concentrations most of the } \\
\text { day and frequently showed symptoms of eye, nose, or } \\
\text { throat irritation }\end{array}$ \\
\hline
\end{tabular}

titles were sent to the plant personnel to classify. Because they were unable to decode these titles, average department exposures were assigned to these job titles. The exposure potentials for the components studied were assigned to each job title that appeared in the employment record according to the assigned job number.

Also, there were some exposure measurements, mostly for workers with highest exposure potential. Although these measurements were not used in the reconstruction of exposures, they were used as a part of validation. The measured exposure values ranged between $<0.02$ to about $6 \mathrm{ppm}$. Most of the measured values were $<1 \mathrm{ppm}$ eight hour time weighted average (TWA). In fact, only nine out of 298 TWA measurements available were $>1 \mathrm{ppm}$ and only one out of nine was $>3 \mathrm{ppm}$. The average of this highest measurement and the four other TWA measurements for the same job was $<1 \mathrm{ppm}$.

The exposure classification intervals were chosen to maximise comparability with the National Cancer Institute study. If, however, a substantial portion of the measured exposures had been $>2 \mathrm{ppm}$, an attempt to reconstruct detailed exposures temporally beyond the available data might have been justified. The data available for this study do not support any further refinement of the classification intervals, and a reconstruction of exposures was not considered necessary.

The measured exposures for several job titles were compared with the estimated exposures based on the job and task descriptions as part of a subjective evalu- ation. The initial estimates were calibrated with the available exposure measurement data in re-evaluation rounds. In this method, artificially altered exposure values for 15 job titles with measured exposure values (test exposures) were mixed with the estimated exposures for 15 job titles without measured exposure values. One third of the test exposure estimates were constructed to be too low and one third too high compared with the measured values. This set was sent to our plant contacts for review. Their corrected test exposures were in complete agreement with the measured values. Although the plant personnel may have been aware of the sampling results or may have had access to these results, their influence on the calibration is unlikely as the PITT investigator of the current study possessed all the original documents.

For several job titles, the available air monitoring data measured could be used to check the validity of the classification scheme by use of all the available measured concentration data to obtain an arithmetic mean for the corresponding ranks. The mean calculated for each rank fell in the intervals assigned for that rank. Although this crude validity check does not provide a full verification of the estimation method, no gross errors were identified. The job class specific classifications were reviewed by plant personnel, who disagreed with or corrected $<10 \%$ of data. None of the corrections pertained to a major class of workers, and the values suggested by the plant personnel were then accepted.

\section{Appendix D: Descriptive analysis of selected Wallingford plant historical exposure data developed for the current study and for the National Cancer Institute study \\ Methods for Comparative Analysis}

The analysis compares individual Wallingford worker exposure values for formaldehyde with and without regard to particulate exposure, as developed independently for the current study and the National Cancer Institute study. ${ }^{1}$ The analysis was performed in both a matched and unmatched fashion and was limited to white males.

Matched analysis-Here an effort was made to locate all white male study members who appeared on both cohort files. Because individual identifiers were unavailable on our version of the National Cancer Institute file, common members were located by matching records on exact date of birth and exact

Appendix C: Definitions of classification factors (covariates) used in the Poisson regression modelling of cohort rates and SMRs for mortality from lung cancer

\begin{tabular}{|c|c|c|c|}
\hline \multirow[b]{2}{*}{ Covariate } & \multirow[b]{2}{*}{ Symbol } & \multicolumn{2}{|c|}{ Levels } \\
\hline & & $n$ & Definition \\
\hline Age group & - & 2 & $<65, \geqslant 65(y)$ \\
\hline Calendar period & - & 3 & $1945-69,1970-79,1980-84$ \\
\hline Year of hire & - & 3 & $1941-46,1947-56,1957-84$ \\
\hline Time since first employment & - & 3 & $<20,20-29, \geqslant 30(y)$ \\
\hline Duration of employment & - & 3 & $\langle 5,5-19, \geqslant 20(y)$ \\
\hline Cumulative formaldehyde exposure & TWE (F) & 4 & $0,<0.05,0.05-1.0, \geqslant 1.0(\mathrm{ppm}-\mathrm{y})$ \\
\hline Cumulative formaldehyde and product particulates & TWE (F/PP) & 4 & $0,<0.05,0.05-1.0, \geqslant 1.0(\mathrm{ppm}-\mathrm{y})$ \\
\hline Cumulative formaldehyde and non-product particulates & TWE (F/NPP) & 4 & $0,<0.05,0.05-1.0, \geqslant 1.0(\mathrm{ppm}-\mathrm{y})$ \\
\hline Cumulative formaldehyde and pigment & TWE (F/Pig) & 2 & $0,>0$ \\
\hline Cumulative product particulate exposure & TWE (PP) & 4 & $0,<0.01,0.01-0.25, \geqslant 0.25\left(\mathrm{mg} / \mathrm{m}^{3}-\mathrm{y}\right)$ \\
\hline Cumulative non-product particulate exposure & TWE (NPP) & 4 & $0,<0.01,0.01-0.25, \geqslant 0.25\left(\mathrm{mg} / \mathrm{m}^{3}-\mathrm{y}\right)$ \\
\hline Duration of exposure to formaldehyde & DUR (F) & 4 & $0,<0.5,0.5-5 \cdot 0, \geqslant 5.0(y)$ \\
\hline Duration of exposure to product particulates & DUR (PP) & 4 & $0,<0.5,0.5-5.0, \geqslant 5.0(y)$ \\
\hline Duration of exposure to non-product particulates & DUR (NPP) & 4 & $0,<0.5,0.5-5 \cdot 0, \geqslant 5.0(y)$ \\
\hline Duration of exposure to pigment & DUR (Pig) & 3 & $0,<0.5, \geqslant 0.5(y)$ \\
\hline Duration of exposure to formaldehyde $\geqslant 0 \cdot 2$ & DUR $(F \geqslant 0 \cdot 2)$ & 4 & $0,<0.5,0.5-5.0, \geqslant 5.0(y)$ \\
\hline $\begin{array}{l}\text { Duration of exposure to formaldehyde } \geqslant 0.7 \\
\text { Average exposure to formaldehyde }\end{array}$ & $\begin{array}{l}\operatorname{DUR}(F \geqslant 0.7) \\
\operatorname{AIE}(F)\end{array}$ & $\begin{array}{l}3 \\
2\end{array}$ & $\begin{array}{l}0,<0.5, \geqslant 0.5(\mathrm{y}) \\
<0.1, \geqslant 0.1(\mathrm{ppm})\end{array}$ \\
\hline $\begin{array}{l}\text { Average exposure to formaldehyde and product } \\
\text { particulates }\end{array}$ & AIE (F/PP) & 2 & $<0.1, \geqslant 0.1(\mathrm{ppm})$ \\
\hline $\begin{array}{l}\text { Average exposure to formaldehyde and non-product } \\
\text { particulates }\end{array}$ & & & \\
\hline $\begin{array}{l}\text { particulates } \\
\text { Average exposure toformaldehyde and pigment* }\end{array}$ & AIE (F/Pig) & 2 & $<0.1, \geqslant 0.1(\mathrm{ppm})$ \\
\hline
\end{tabular}

^Based on exposed jobs only. 
date of hire. Although the matched analysis is limited to a subset of the two Wallingford cohorts, it does provide the most direct comparison of the exposures estimated in the two studies.

Before matching, the two white male cohort files were made as comparable as possible by defining a common Wallingford cohort as:

- All white male workers hired between plant start up (around 1941) and 31 December 1965

- Exclude workers who died before 1945

- Mortality follow up to the end of 1979

- Exposure values were computed from date of hire to date of end of employment or 31 December 1979

To meet these criteria the following changes were made to the present cohort file:

- Exclude workers hired after 1965

- Workers employed after 31 December 1979 were censored on 31 December 1979

The matching on exact dates of birth and hire resulted in the numbers of study members (table D-1):

Possible reasons for the discrepancies include:

- Discrepancies in birth and hire dates

- Differences in cohort inclusion criteria relative to job title, work area, etc

- Different records available or missing at the plant site during the time of the two cohort enumerations

The matched analysis was based on the 2990 records present in both files. It is not known whether the reasons for the discrepancies are in any way related to fomaldehyde exposures at the plant.

Table D-1 Results of matched analysis

\begin{tabular}{llll}
\hline & $\begin{array}{l}\text { In present } \\
\text { file }\end{array}$ & $\begin{array}{l}\text { Not in } \\
\text { present file }\end{array}$ & Total \\
\hline $\begin{array}{llll}\text { In National Cancer } \\
\begin{array}{l}\text { Institute file } \\
\text { Not in National Cancer }\end{array}\end{array}$ & 2990 & 666 & 3656 \\
$\begin{array}{l}\text { Institute file } \\
\text { Total }\end{array}$ & 1758 & - & 1758 \\
\hline
\end{tabular}

Table D-1a Results of matched analysis ( $n=2990)$

\begin{tabular}{llll}
\hline & Present study & & \\
\cline { 2 - 4 } & Exposed to $F$ & Unexposed to $F$ & Total \\
\hline NCI study: & 2519 & 216 & 2735 \\
Exposed to F & 12 & 243 & 255 \\
Unexposed to F & 2531 & 459 & 2990 \\
Total & & & \\
\hline
\end{tabular}

Table D-1b Results of matched analysis $(n=2990)$

\begin{tabular}{llll}
\hline & \multicolumn{2}{l}{ Present study } & \\
\cline { 2 - 4 } & Exposed to F/Part & Unexposed to F/Part & Total \\
\hline NCI study: & & & \\
Exposed to F/Part & 2466 & 213 & 2679 \\
Unexposed to F/Part & 30 & 281 & 311 \\
Total & 2496 & 494 & 2990 \\
\hline
\end{tabular}

Unmatched analysis - In this analysis exposure values were computed separately for the $\mathbf{3 6 5 6}$ study members in the National Cancer Institute file and the 4748 study members in the current study file, under the assumption that these cohorts were comparably defined. Although it is known that these cohorts contain a relatively large number of different members, this analysis does relate more closely to the actual cohorts that were studied.

For each study member the following exposure indicators were computed across the entire work history, where particulate exposure refers to exposure to either product or non-product particulates:

- Duration of employment regardless of exposure (DOE)

- Duration of exposure

To formaldehyde (DUR(F))

To formaldehyde in the presence of particulates (DUR(F)/Part)

- Cumulative exposure (time weighted)

To formaldehyde (TWE(F))

To formaldehyde in the presence of particulates (TWE(F)/Part)

Average intensity of exposure computed across exposed jobs only

To formaldehyde (AIE(F))

To formaldehyde in the presence of particulates (AIE(F)/Part)

Results

Matched analysis-Tables D-1a and D-1b show the distribution of the 2990 pairs according to qualitative exposure to $F$ and $F / P a r t$. Overall, the agreement is good between the two studies. For exposure to $F$ and $F / P a r t$ there is a greater frequency of pairs classified as exposed by National Cancer Institute and unexposed by the present study compared with the opposite classification.

Table D-2 shows selected summary statistics for the exposure indicators computed in the two studies. In general, the agreement is excellent for DOE and DUR(F), good for DUR(F)/Part, TWE(F) and TWE(F)/Part and poor for $\operatorname{AIE}(F)$ and $\operatorname{AIE}(\mathrm{F}) /$ Part. The median $\mathrm{AIE}(\mathrm{F})$ and $\mathrm{AIE}(\mathrm{F}) /$ Part values from National Cancer Institute are more than ten times larger than the corresponding values from the present study.

Unmatched Analysis-Table D-3 shows selected summary statistics for the exposure indicators computed in the two studies. It is more difficult to assess comparability here due to the different study members in each file. Nevertheless, the basic patterns observed in the matched analysis (table D-2) are evident.

Table D-4 shows the distribution of study members by qualitative exposure status to $F$ and $F / P a r t$. As in the matched analysis, the overall level of agreement is good, with a somewhat larger percentage of study members assigned to $F$ and $F / P a r t$ exposures in the National Cancer Institute study.

This project was supported by a contract between the Unis project was supported by a contract between the Company. We gratefully acknowledge the assistance and cooperation of Dr James Collins, Larry Drapela, and Judy Saipher, a well as other American Cyanamid Company employees and
former employees who participated in this research effort. In

Table D-2 Results of matched analysis $(n=2990)$

\begin{tabular}{|c|c|c|c|c|c|c|c|c|c|c|c|c|c|c|}
\hline & \multicolumn{2}{|l|}{$D O E$} & \multicolumn{2}{|c|}{ DUR $(F)$} & \multicolumn{2}{|c|}{ DUR (F)/Part } & \multicolumn{2}{|c|}{$T W E(F)$} & \multicolumn{2}{|c|}{$T W E(F) / P a r t$} & \multicolumn{2}{|c|}{$A I E(F)$} & \multicolumn{2}{|c|}{ AIE (F)/Part } \\
\hline & $N C I$ & Present & $N C I$ & Present & $N C I$ & Present & $N C I$ & Present & $N C I$ & Present & $N C I$ & Present & $\overline{N C I}$ & Presen \\
\hline $\begin{array}{l}\text { Min } \\
25 \% \\
50 \% \\
75 \% \\
\text { Max } \\
\text { Mean } \\
\text { SD } \\
\text { Corr }\end{array}$ & $\begin{array}{r}0.08 \\
0.33 \\
1.36 \\
8.23 \\
38.16 \\
6.19 \\
9.03\end{array}$ & $\begin{array}{r}0.08 \\
0.31 \\
1.16 \\
7.63 \\
37.84 \\
5.97 \\
8.99\end{array}$ & $\begin{array}{r}0 \\
0.21 \\
0 \cdot 75 \\
4 \cdot 69 \\
37.95 \\
4.63 \\
7 \cdot 72 \\
0\end{array}$ & $\begin{array}{l}0 \\
0 \cdot 15 \\
0 \cdot 57 \\
3 \cdot 64 \\
36 \cdot 32 \\
3.95 \\
7 \cdot 07\end{array}$ & $\begin{array}{r}0 \\
0.18 \\
0.61 \\
3.50 \\
37.95 \\
3.91 \\
6.98\end{array}$ & $\begin{array}{r}0 \\
0.14 \\
0.52 \\
2.98 \\
34.00 \\
3.30 \\
6.16\end{array}$ & \begin{tabular}{r}
\multicolumn{1}{l}{0} \\
$0 \cdot 21$ \\
$0 \cdot 73$ \\
$3 \cdot 80$ \\
$45 \cdot 28$ \\
3.32 \\
5.52
\end{tabular} & $\begin{array}{l}0 \\
0 \\
0.05 \\
0.47 \\
22.68 \\
0.63 \\
1.65\end{array}$ & $\begin{array}{r}0 \\
0 \cdot 19 \\
0 \cdot 59 \\
2 \cdot 89 \\
34.92 \\
2 \cdot 75 \\
4 \cdot 76 \\
0\end{array}$ & $\begin{array}{l}0 \\
0 \\
0.05 \\
0.40 \\
22.68 \\
0.63 \\
1.65\end{array}$ & $\begin{array}{l}0 \\
0.60 \\
1.00 \\
1 \cdot 16 \\
2.06 \\
0.87 \\
0.41\end{array}$ & $\begin{array}{l}0 \\
0 \cdot 02 \\
0 \cdot 07 \\
0 \cdot 20 \\
0 \cdot 70 \\
0 \cdot 12 \\
0 \cdot 14\end{array}$ & $\begin{array}{l}0 \\
0.56 \\
0.98 \\
1.15 \\
2.06 \\
0.85 \\
0.42\end{array}$ & $\begin{array}{l}0 \\
0 \cdot 02 \\
0 \cdot 08 \\
0 \cdot 20 \\
0 \cdot 70 \\
0 \cdot 12 \\
0 \cdot 14\end{array}$ \\
\hline
\end{tabular}

NCI = National Cancer Institute; $M$ in = minimum value; $25 \%=25$ th percentile value; $50 \%=50$ th percentile value $($ median $) ; 75 \%=75$ th percentile value $\mathrm{Max}=$ Maximum value; Mean = Arithmetic mean; Corr = Correlation coefficient (Pearson); Refer to appendix C for definitions of exposure variables. 
Table D-3 Results of unmatched analysis NCI $(n=3656)$, present study $(n=4748)$

\begin{tabular}{|c|c|c|c|c|c|c|c|c|c|c|c|c|c|c|}
\hline & \multicolumn{2}{|l|}{$D O E$} & \multicolumn{2}{|c|}{$D U R(F)$} & \multicolumn{2}{|c|}{ DUR (F)/Part } & \multicolumn{2}{|c|}{$T W E(F)$} & \multicolumn{2}{|c|}{$T W E(F) /$ Part } & \multicolumn{2}{|c|}{$A I E(F)$} & \multicolumn{2}{|c|}{$A I E(F) / P a r t$} \\
\hline & $N C I$ & Present & $N C I$ & Present & $N C I$ & Present & $N C I$ & Present & $N C I$ & Present & $N C I$ & Present & $N C I$ & Present \\
\hline Min & 0 & 0 & 0 & 0 & 0 & 0 & 0 & 0 & 0 & 0 & 0 & 0 & 0 & 0 \\
\hline $25 \%$ & 0.34 & $0 \cdot 15$ & 0.22 & 0.04 & $0 \cdot 18$ & 0.04 & 0.22 & 0 & 0.19 & 0 & 0.60 & 0.02 & 0.57 & 0.02 \\
\hline $50 \%$ & 1.41 & 0.64 & 0.77 & 0.31 & 0.63 & 0.29 & 0.76 & 0.02 & 0.61 & 0.02 & 1.00 & 0.05 & 0.98 & 0.05 \\
\hline $75 \%$ & 8.67 & 4.55 & 5.02 & $2 \cdot 15$ & 3.76 & 1.85 & $\begin{array}{l}3.89 \\
3.89\end{array}$ & 0.29 & 3.14 & 0.26 & $1 \cdot 16$ & 0.20 & $\begin{array}{l}0.98 \\
1.15\end{array}$ & 0.20 \\
\hline $\operatorname{Max}$ & 38.16 & 38.15 & 37.95 & 36.32 & 37.95 & 34.00 & 45.28 & $22 \cdot 68$ & 40.52 & 22.68 & $2 \cdot 16$ & 0.70 & $2 \cdot 16$ & 0.70 \\
\hline Mean & 6.25 & 4.88 & $4 \cdot 70$ & 3.20 & 4.02 & 2.67 & 3.38 & 0.51 & 2.83 & 0.50 & 0.88 & 0.11 & 0.85 & 0.12 \\
\hline SD & 9.03 & $8 \cdot 38$ & 7.82 & 6.51 & 7.07 & 5.66 & 5.55 & 1.44 & 4.84 & 1.43 & 0.42 & 0.14 & 0.42 & 0.14 \\
\hline
\end{tabular}

$\mathrm{NCI}=$ National Cancer Institute; $\mathrm{Min}=$ minimum value; $25 \%=25$ th percentile value; $50 \%=50$ th percentile value $($ median); $75 \%=75$ th percentile value; Max = maximum value; Mean $=$ arithmetic mean; refer to appendix $\mathrm{C}$ for definitions of exposure variables.

Table D-4 Results of unmatched analysis: National Cancer Institute $(n=3656)$, present study $(n=4748)$

\begin{tabular}{|c|c|c|c|c|}
\hline & \multicolumn{2}{|l|}{ Exposure to $F$} & \multicolumn{2}{|c|}{ Exposure to F/Part } \\
\hline & $\begin{array}{l}\text { Ever exposed } \\
n(\%)\end{array}$ & $\begin{array}{l}\text { Never exposed } \\
n(\%)\end{array}$ & $\begin{array}{l}\text { Ever exposed } \\
n(\%)\end{array}$ & $\begin{array}{l}\text { Never exposed } \\
n(\%)\end{array}$ \\
\hline $\begin{array}{l}\text { National Cancer } \\
\text { Institute study }\end{array}$ & $3351(91 \cdot 7)$ & $305(8 \cdot 3)$ & $3284(89 \cdot 8)$ & $372(10 \cdot 2)$ \\
\hline Present study & $3953(83 \cdot 3)$ & $795(16 \cdot 7)$ & $3897(82 \cdot 1)$ & $851(17 \cdot 9)$ \\
\hline
\end{tabular}

particular, we acknowledge the assistance of Dr Lorraine Lucas who also contributed many helpful comments on the manuscript. We also acknowledge the work of the University of
Pittsburgh staff: Stephen Sefcik, Michele LaValley, Howard Lebow, and Linda Kobus.

1 Blair A, Stewart P, O'Berg M, Gaffey W, Walrath J, Ward J, et al. Mortality among industrial workers exposed to formaldehyde. $\mathcal{F}$ Natl Cancer Inst 1986;76:195-215.

2 Swenberg JA, Kerns WD, Mitchell RI, Gralla EJ, Pavkov $\mathrm{KL}$. Induction of squamous cell carcinomas of the rat nasal cavity by inhalation exposure to formaldehyde vapor. Cancer Res 1982;40:3398-402.

3 Albert RE, Sellakumar AR, Laskin S, Kuschner M, Nelson A, Snyder CA. Gaseous formaldehyde and hydrochloride induction of nasal

4 Consensus Workshop on Formaldehyde-Report. Environ Health Perspect 1984;58:323-81.

5 Hunter's diseases of occupations. In: Raffle PAB, Lee WR, McCallum RI, Murray R, eds. London: E Arnold, 1987.

6 Blair A, Stewart PA, Hoover RN, Fraumeni Jr JF. Cancers of the nasopharynx and oropharynx and formaldehyde exposure [letter]. I Natl Cancer Inst 1987;78:191.

7 Collins JJ, Caporossi JC, Utidjian HHD [letter]. Formaldehyde exposure and nasopharyngeal cancer: reexamination of the National Cancer Institute study, and an update of one plant. F Natl Cancer Inst 1987;78:192.

8 Collins J, Caporossi JC, Utidjian HHD. Formaldehyde exposure and nasopharyngeal cancer: re-examination of exposure and nasopharyngeal cancer: re-examination of
the National Cancer Institute study and update in one the National Cancer Institute study and update

9 Blair A, Stewart PA, Hoover RN. Mortality from lung cancer among workers employed in the formaldehyde industries. Am 于 Ind Med 1990;17:683-99.

10 Marsh GM, Stone RA, Henderson VL. Lung cancer mortality among industrial workers exposed to formaldehyde: a Poisson regression analysis of the National Cancer Institute study. Am Ind Hyg Assoc F 1992;53:681-91.

11 Marsh GM, Stone RA, Henderson VL. A reanalysis of the National Cancer Institute study on mortality among industrial work

12 Robins JM, Pambrun M, Chute C, Blevins D. Estimating the effect of formaldehyde exposure on lung cancer and
non-malignant respiratory disease (NMRD) mortality using a new method to control for the healthy worker surusing a new method to control for the healthy worker sur-
vivor effect. In: Hogstedt C, Reuterwall C, eds. Progress vivor effect. In: Hogstedt C, Reuterwall C, eds. Progress
in occupational epidemiology. Amsterdam: Elsevier (Bioin occupational epidemiology. A

13 Sterling TD, Weinkam J. Reanalysis of lung cancer mortality in the National Cancer Institute study on mortality among industrial workers exposed to formaldehyde. $\mathcal{F}$ Occup Med 1988;30:895-901.

14 Sterling TD, Weinkam JJ. Reanalysis of lung cancer mortality in the National Cancer Institute study on mortality among industrial workers to formaldehyde: add

15 Stewart PA, Schairer C, Blair A. Comparison of jobs, exposure, and mortality risks for short-term and long-term workers. $\mathcal{f}$ Occup Med 1990;32:703-8.
16 Marsh GM, Stone RA, Esmen NA, Henderson VL. Mortality patterns among chemical plant workers exposed to formaldehyde and other substances. $\mathcal{F}$ Natl Cancer Inst 1994;88:384-6.

17 Marsh GM, Enterline PE. A method for verifying the completeness of cohorts used in occupational mortality studies. fleteness of cod 1979;21:665-70.

18 Marsh GM. A computerized approach to verifying study population data in occupational epidemiology. $\mathcal{F}$ Occup Med 1982;24:596-601.

19 Esmen NA. Retrospective industrial hygiene surveys. $\mathrm{Am}$ Ind Hyg Assoc 7 1979;40:58-65.

20 Corn M, Esmen NA. Workplace exposure zones for classification of employee exposures to physical and chemical cation of employee exposures to physical
agents. Am Ind Hyg Assoc $\mathcal{F} 1979 ; 40: 47-57$.

21 Kromhout H, Oostendorp Y, Heedrik D, Boleij JSM Agreement between qualitative exposure estimates and quantitative exposure measurements. Am $\mathcal{F}$ Ind $\mathrm{Med}$ 1987;12:551-62.

22 Hawkins NC, Evans JC. Subjective estimation of toluene exposures: a calibration study of industrial hygienists. Appl Ind Hyg 1989;4:61-8.

23 Marsh GM, Preininger ME. OCMAP: a user-oriented occupational cohort mortality analysis program. American Statistician 1980;34:245-6.

24 Marsh GM, Ehland J, Paik M, Preininger M, et al. OCMAP/PC: a user-oriented occupational cohort mortality analysis program for the IBM PC. American Statistician 1986;40:308-9.

25 Caplan RJ, Marsh GM, Enterline PE. A generalized effective in expidemiologic investigations. Comparative Biomedical in epidemiologic investiga
Research 1983;16:587-96.

26 Marsh GM, Ehland J, Sefcik S, Alcorn C. Mortality and population data system (MPDS). Pittsburgh, PA University of Pittsburgh, 1996. (Department of Biostatistics technical report.)

27 Bailer JC, Ederer F. Significance factors for the ratio of a Poisson variable to its expectation. Biometrics 1964;20: 639-42.

28 Breslow NE, Day NE. Statistical methods in cancer research. Lyons: International Agency for Research on Cancer, 1987;4:135-53.

29 Baker RJ, Nelder JA. GLIM (generalized linear interactive modeling). Release 3.77 [computer software]. Oxford: Royal

30 American Conference of Governmental Industrial Hygienists. 1979 Threshold limit values for chemical substances and physical agents. Cincinnati, Ohio: ACGIH TLV Committee, 1979 .

31 National Institute of Occupational Safety and Health. NIOSH pocket guide to chemical hazards. Cincinnati, Ohio: US Department of Health and Human Services, Centers for Disease Control, 1990. (DHHS(NIOSH) Publ No 90-117.)

32 American Conference of Governmental Industrial Hygienists. 1993-4 Threshold values for chemical substances and physical agents and biological exposure indices. Cincinnati, Ohio: ACGIH TLV Committee, 1993.

33 Marsh GM, Enterline PE, Stone RA, Henderson VL. Mortality among a cohort of US man-made mineral fiber Mortality among a cohort of US man-made mineral fiber
workers: 1985 follow-up. 7 Occup Med 1990;32:594-604.

34 Checkoway H, Pearce NE, Crawford-Brown DJ. Research methods in occupational epidemiology. Oxford: Oxford methods in occupational

35 Gilbert ES. Some confounding factors in the study of mortality and occupational exposures. Am $\mathcal{F}$ Epidemiol 1982; 116:177-88.

36 Lamm SH, Levine MS, Starr JA, Tirey SA. Analysis of excess lung cancer risk in short-term employees. $A m \mathcal{F}$ Epidemiol 1988;1127:1202-9.

37 Lucas LJ. Misclassification of nasopharyngeal cancer [letter]. I Natl Cancer Inst 1994;86:1556-7.

38 Marsh GM, Stone RA, Henderson VL. Misclassification of nasopharyngeal cancer [letter]. $\mathcal{F}$ Natl Cancer Inst 1994, 86:1557. 